\title{
Studies in the Diabetic Mutant Mouse: II. Electron Microscopy of Pancreatic Islets*
}

\author{
A.A. LIKk** and W.L. ChICK*** \\ Elliott P. Joslin Research Laboratory, Department of Pathology and Medicine, Harvard Medical School, The Peter Bent
} Brigham Hospital and The Joslin Diabetes Foundation, Inc., Boston, Massachusetts, USA

Summary. Electronmicroscopic studies were performed on the pancreatic islets of normal mice (C 57 BL/ $\mathrm{KsJ})$ and of diabetic mutants $\left(\mathrm{C} 57 \mathrm{BL} / \mathrm{K}_{\mathrm{s}-d b / d b)}\right.$ at all stages of the syndrome. The ultrastructural appearance of the islets of prehyperglycemic mutants (Blood Glucose $<120 \mathrm{mg} / 100 \mathrm{ml}$ ) did not differ from that of normal mice. The two could not be differentiated without the aid of radioautography, which demonstrated that the beta cells of: prehyperglycemic mutants incorporated thymidine- ${ }^{3} \mathrm{H}$ with greater frequency. Beta cells of early hyperglycemic mice (BG $130-200 \mathrm{mg} / 100 \mathrm{ml}$ ) revealed partial secretory degranulation, increased quantities of rough endoplasmio reticulum and enlarged Golgi structures. Beta cell necrosis was most common in mice with established hyper glycemia during the period of most rapid blood glucose elevation. It negated the effects of the short lived increase in beta cell proliferation and was eventually responsible for a reduction in beta cell mass and relative insulin insufficiency. The presence of unique intra-islet ductal structures and acinar cells later in the syndrome is unknown in other diabetic models. The proliferating ductal epithelial cells presumably gave rise to ciliated cells, mucous goblet or Paneth cells and pancreatic acinar cells, but no evidence of beta cell neogenesis was obtained. "Virus-like" particles were identified within intact and necrotic beta cells and intra-islet acinar cells.

Etudes de la mutation dbdb chez la souris. II. Microscopie électronique des îlots pancréatiques

Résumé. Des études au microscope électronique ont été faites sur des îlots pancréatiques de souris normales (C57BL/KsJ) et de mutants diabétiques (C57BL/Ks$d b / d b)$ à tous los stades du syndrome. L'aspect ultrastructurel des îlots des mutants préhyperglycémiques (taux de glucose sanguin $120 \mathrm{mg} \%$ ) ne diffère pas de celui de souris normales. II n'a pas été possible de distinguer les deux catégories sans l'aide de l'autoradiographie qui montre une plus grande fréquence d'incorporation de la ${ }^{3} \mathrm{H}$ thymidine dans les cellules $\beta$ des animaux préhyperglycémiques. Dans les cellules $\beta$ de souris présentant depuis peu une hyperglycémie (glucose sanguin entre 130 et 200 $\mathrm{mg} \%$ ), on observe une dégranulation partielle, une augmentation du réticulum endoplasmique granulaire et un élargissement du complexe de Golgi. Des nécroses de cellules $\beta$ sont très fréquentes chez les souris ayant une hyperglycémie manifeste au cours de la période de l'ascension rapide du glucose sanguin. Ce phénomène annule les effets de l'augmentation passagère dans la prolifération des cellules $\beta$ et pourrait être éventuellement responsable de la réduction de la masse des cellules $\beta$ et du manque relatif en insuline. La présence de structures tubulaires uniques dans les îlots et de cellules acinaires à un stade plus avancé du syndrome n'a pas été décrite dans d'autres types de diabète. La prolifération des cellules tubulaires épithéliales est probablement à l'origine des cellules ciliées, des cellules à mucus ou cellules de Paneth et des cellules pancréatiques acinaires, mais on n'a pas pu démontrer une néogénèse des cellules $\beta$. Des particules ressemblant à des virus ont pu être identifiées dans des cellules $\beta$ intactes et nécrotiques ainsi que dans les cellules acinaires intra-insulaires.

Der Diabetes der dbdb-Maus. II. Elektronenmikroskopische Untersuchungen der Langerhans'schen Inseln

Zusammenfassung. Die Langerhans'schen Inseln normaler (C57BL/KsJ) und hereditär diabetischer (C57BL/ $\mathrm{Ks}-d b / d b)$ Mäuse wurden mit dem Elektronenmikroskop untersucht. Vor Auftreten des hyperglykämischen Syndroms konnten in den Inseln künftig diabetischer Tiere keine ultrastrukturellen Veränderungen festgestellt werden. - Dagegen zeigten autoradiographische Untersuchungen mit Thymidin- ${ }^{3} \mathbf{H}$ eine deutlich erhöhte Inkorporation der markierten Substanz in die Inseln der künftig hyperglykämischen Tiere. Die B-Zellen mäßig hyperglykämischer Tiere waren teilweise degranuliert, ihr ergastoplastisches Reticulum war deutlich sichtbar und der Golgi-Komplex vergrößert. B-Zellnekrose war bei Tieren mit länger dauernder Hyperglykämie und im Verlauf des schnellen Anstiegs der Blutzuckerkonzentrationen am häufigsten zu sehen. Trotz vorübergehender Steigerung der B-Zellproliforation nahm die Gesamtzahl der B-Zellen progressiv ab. Besondere Aufmerksamkeit wird den bisher bei keinem andern hyperglykämischen Zustand beschriebenen und bei $d b / d b$-Mäusen in einem fortgeschrittenen Stadium des Syndroms anzutreffenden, innerhalb der Inseln lokalisierten tubulären Strukturen geschenkt. Die proliferierenden epithelialen Zellen schienen für das Auftreten von mit Zilien versehenen Zellen, Schleimzellen und acinären Zellen verantwortlich zu sein, doch konnte kein Hinweis für das Vorkommen einer Neubildung von B-Zellen aus exokrinen Mutterzellen gefunden werden. Sowohl in normalen und nekrotischen B-Zellen als auch in den acinären Zellen wurden von Viren nicht zu unterscheidende Strukturen festgestellt.

Key-words: Spontaneous diabetes, genotype: C57BL/ $\mathrm{K}_{\mathrm{s}-} d b / d b$, hereditary diabetes in mice, mutation: diabetes, pancreatic islets, ultrastructure, islets of Langerhans, beta cell necrosis, virus and beta cell necrosis, type particle.
In this paper we will report the results of electron microscopic studies of the pancreatic islets of normal

* Supported in part by USPHS Grants AM-12538, AM-05077, AM-09584

** USPHS Research Career Development Awardee, Grant K4-AM-7394.

*** USPHS Special Postdoctoral Fellowship Awardee, Grant F3-AM-36335.
(C $57 \mathrm{BL} / \mathrm{KsJ}_{\text {) }}$ and diabetic mutant (C $57 \mathrm{BL} / \mathrm{K}_{\mathrm{s}-} d b /$ db)mice, at all stages of the syndrome. An account of the light microscopic and radioautographic findings was given in a companion paper [9], wherein a brief description of the mutation, and a resumé of previous publications were also presented.

The present efforts were undertaken in order to document any morphologic changes in the islets asso- 


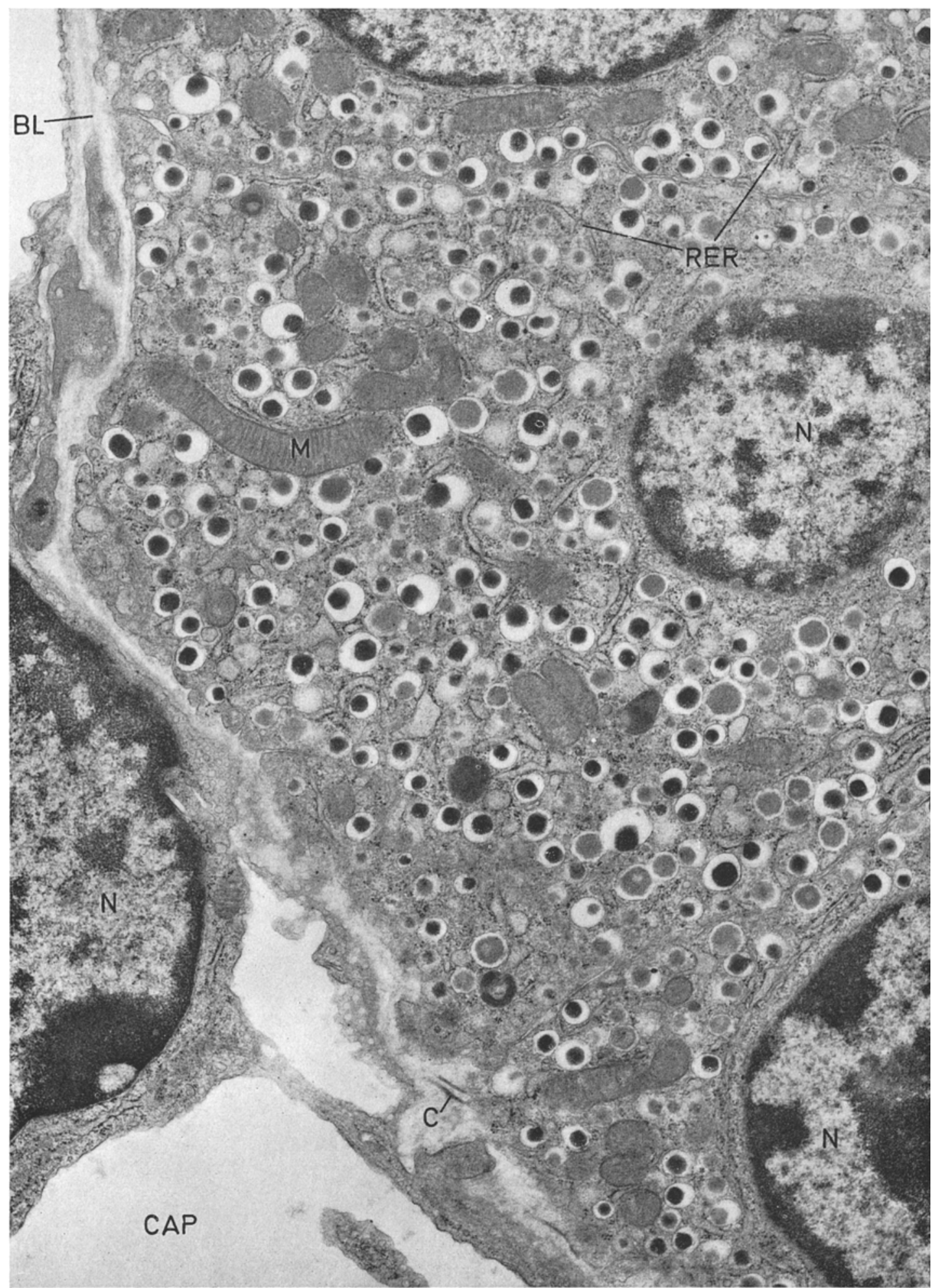

Fig. 1. Beta cells, normal (C57 BL/KsJ) mouse: secretory storage granules are abundant and contained within loosely fitting smooth sacs. Mitochondria are slender. Rough endoplasmic reticulum is sparse. The capillary is
1. CAP : Capillary
2. BL: Basal Lamina
6. Cil: Cilium
10. M: Mitochondrion
3. C: Collagen Fibril
7. N: Nucleus
4. Ne: Non Myelinated Nerve
8. RER : Rough Endoplasmic
1. mv: microvillus
9. G: Golgi
12. Lys: Lysosome
13. CM: Cell Membrane

lined by fenestrated endothelial cells. Approximately $14250 \times$

$\begin{array}{cccc}\text { 5. Ce: Centriole } & 9 . \mathrm{G}: \quad \text { Golgi } & 14 . \text { mf: myelin figures } \\ \text { The micrographs are from tissue samples prepared with aldehyde fixatives, with the exception of Figs. } 8,9,11,12 \text { and } 1\end{array}$ 


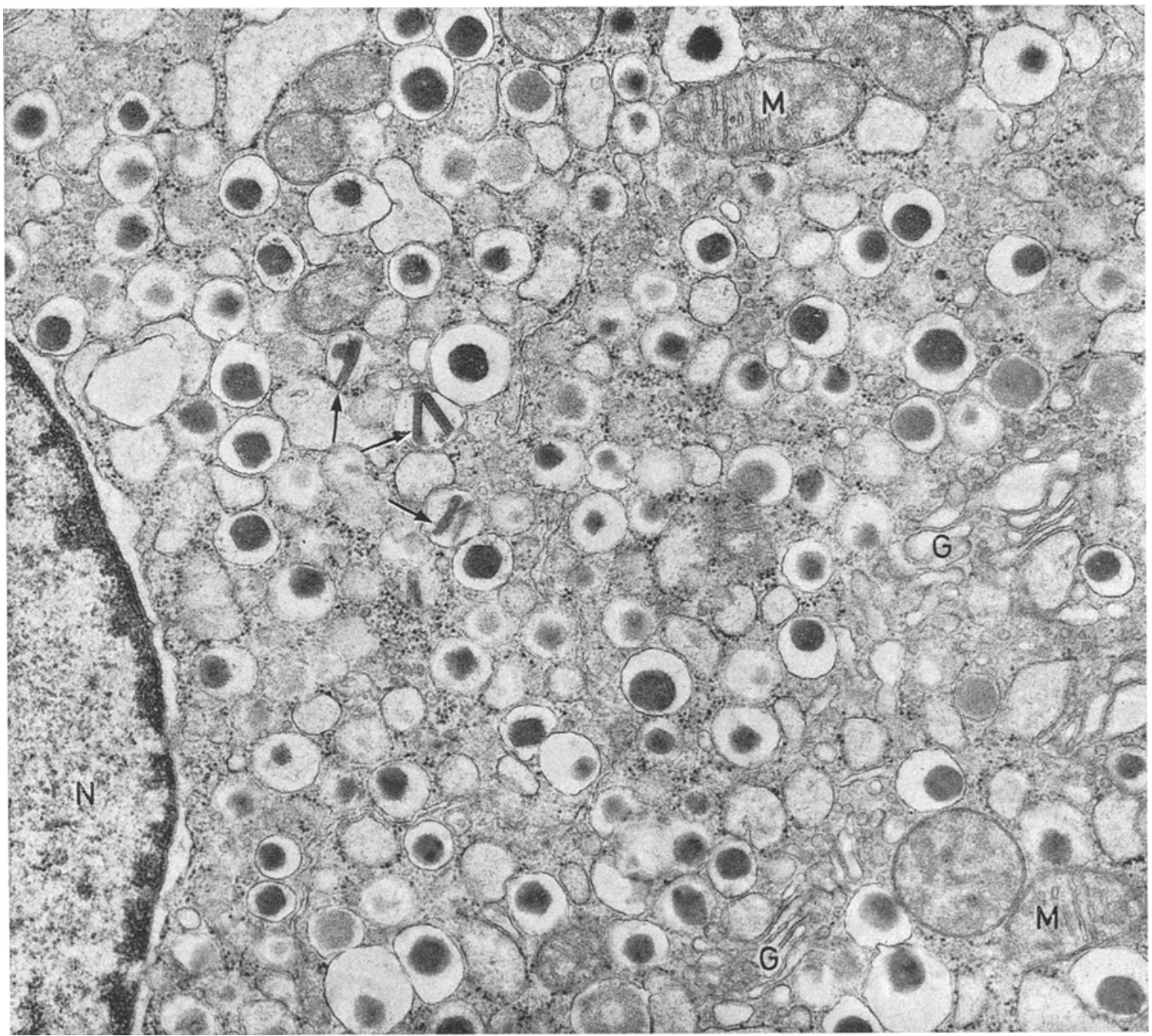

Fig. 2. Normal beta cell: secretory granules vary in appearance. Electron dense, electron lucent and crystalline (arrows) forms are visible. The Golgi complex is small. Approximately $22000 \times$

ciated with the major physiologic events of the syndrome. In so doing, special emphasis was placed upon an endeavor to: 1. Examine the islets of pre-hyperglycemic mutants ( $\mathrm{BG}<120 \mathrm{mg} / 100 \mathrm{ml}$ ) to determine whether any morphologic defects antedate the onset of carbohydrate intolerance. 2. Identify the islet cells (alpha vs beta) responsible for the uptake of thymidine- ${ }^{3} \mathrm{H}$ administered to early hyperglycemic mutants $[9,1]$. 3. Document the occurrence and determine, if possible, the etiology of beta cell necrosis. 4 . Study the fine structure of the epithelial cells lining the proliferating ducts, with special emphasis on their ability to differentiate into endocrine islet cells. 5. Examine the pancreatic acinar cells which are situated within many islets of mutants during the latter portion of the disease.

\section{Materials and Methods}

For information concerning the source of animals, diet, methods of blood glucose (BG) and serum im- munoreactive insulin (IRI) analyses, methods of sacrifice and light microscopic examinations, the reader is referred to the accompanying publications in this issue $[9,1]$.

Fifty-three mutants and 18 age-matched normal mice were used for the electron microscopic examination. The mutants included animals at all four stages of the syndrome [9]. The pancreata were fixed at room temperature by immersion or perfusion: the latter was accomplished by rapidly injecting fixative under pressure into the left ventricle, preceded by severing the inferior vena cava. Fixatives included $3 \%$ glutaraldehyde, buffered with sodium cacodylate $(0.1 \mathrm{M}), \mathrm{pH}$ $7.4-7.6$, or Karnovsky's paraformaldehyde-glutaraldehyde solution, diluted 1:1 with sodium cacodylate $(0.1 \mathrm{M})$ final $\mathrm{pH} 7.2-7.5$ [5]. Calcium chloride $(0.005 \mathrm{M})$ was added to both aldehyde fixatives. After fixation for $2 \mathrm{~h}$, tissues were washed in $0.1 \mathrm{M}$ sodium cacodylate, frequently containing $10 \%$ sucrose, for variable periods of time, and subsequently post fixed 


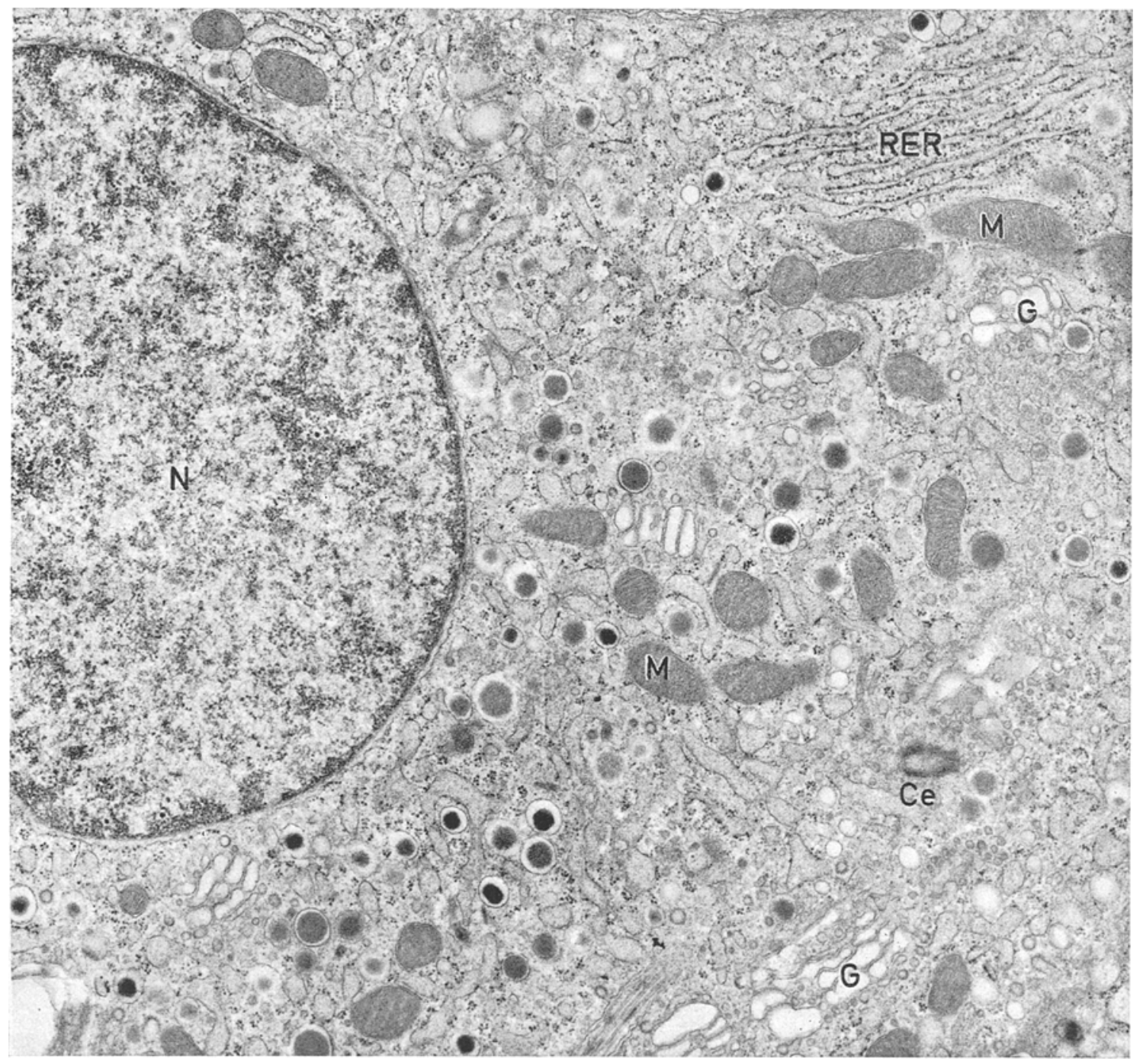

Fig. 3. Normal beta cells showing evidence of increased synthesis and secretion. Secretory granules diminished. Rough endoplasmic reticulum and Golgi elements are increased. Approximately $14250 \times$

at $0-4^{\circ} \mathrm{C}$ in $1.33 \%$ osmium tetroxide buffered with S-collidine $(0.07 \mathrm{M})$, with added sucrose $(0.122 \mathrm{M})$ and calcium chloride $(0.005 \mathrm{M})$; final $\mathrm{pH}$ was $7.4-7.6$. In selected instances, pancreatic fragments were also primarily fixed at $0-4^{\circ} \mathrm{C}$ in osmium tetroxide, prepared as described above. All tissues were rapidly dehydrated in a graded series of ethanol solutions and embedded in epon 812 [13]. Sections cut at 1 micron were stained with $1 \%$ toluidine-blue-0 in $1 \%$ borax, for light microscopic identification of pancreatic islets. Thin sections were then prepared with an LKB ultratome using duPont diamond knives and examined in an RCA EMU 3G microscope after sequential staining with $95 \%$ aqueous uranyl acetate and lead citrate [18].

Electron microscopic radioautography was carried out on pancreatic samples from 2 early hyperglycemic mutants. The method of thymidine ${ }^{3} \mathrm{H}$ administration has already been described $[9,1]$. Pancreatic islets identified in 1 micron epon sections were subjected to light microscopic radioautography using the same techniques employed for paraffin sections. Those islets with several heavily labeled nuclei were selected and sections with pale gold interference colors were picked up on uncoated Athene grids and coated with Ilford-L4 photographic emulsion. After exposure for from 4 to 6 weeks in Drierite-containing light-tight boxes at 0 to $4^{\circ} \mathrm{C}$, the emulsion was developed in freshly prepared Kodak D-19 developer, fixed in acid fixer, washed and stained with lead citrate.

Normal mice

\section{Results}

The pancreatic islets of normal C $57 \mathrm{BL} / \mathrm{Ks} . J$ mice can not be distinguished from those of other inbred, hybrid [12] or random bred mouse species [11] studied in this laboratory. 


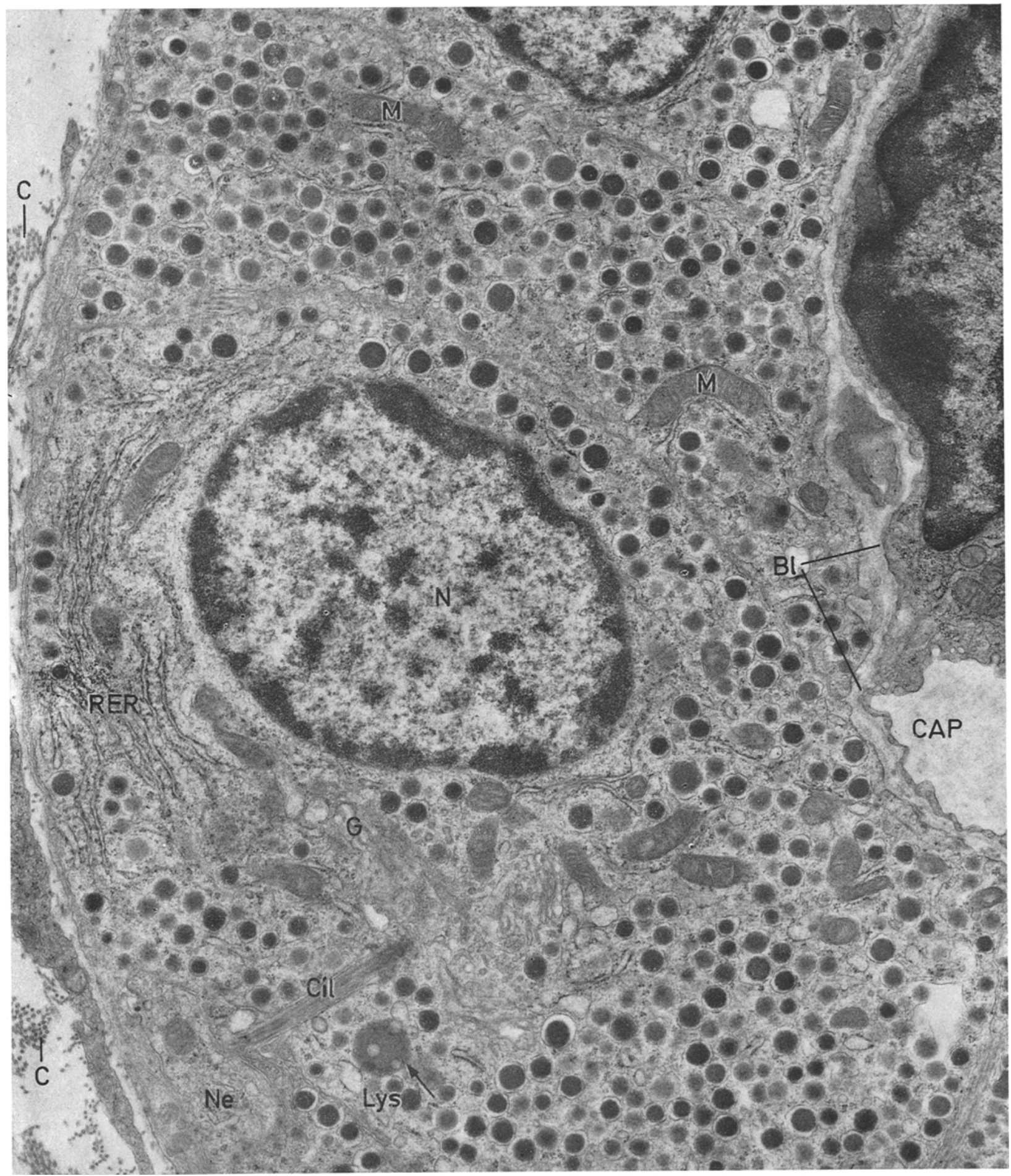

Fig. 4. Alpha cells, normal mouse: secretory storage granules are uniformly electron dense and contained in tightly fitting sacs. Rough endoplasmic reticulum and Golgi are compact. Occasional lysosomes are present. Surrounding collagen fibrils delineate periphery of islet. Approximately $14250 \times$ 


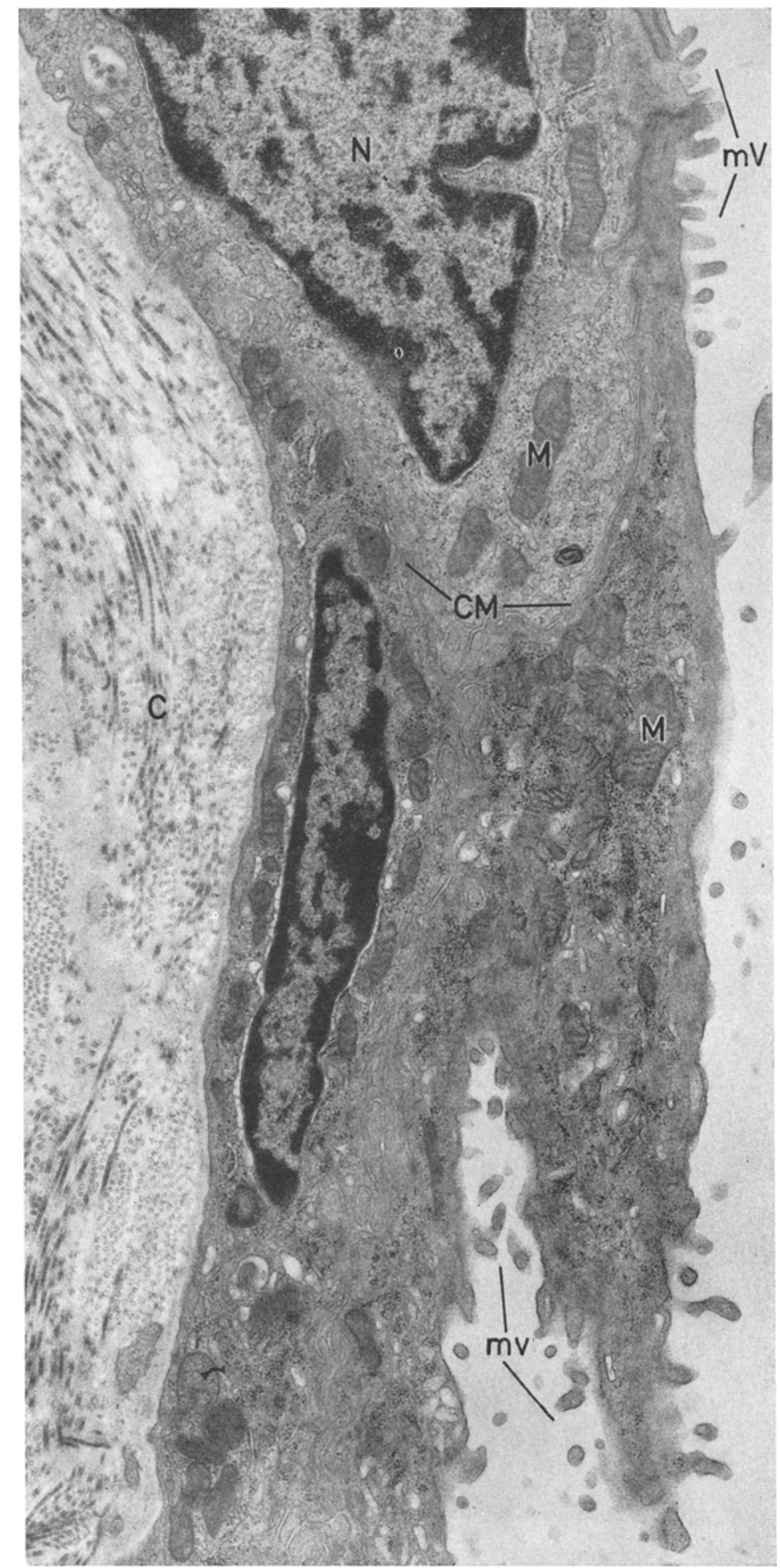

Fig. 5. Small exocrine duct, normal mouse: low cuboidal epithelial cells are without differentiated organelles. Mitochondria are small and without granules. Surface microvilli are visible. Approximately $14250 \times$ 


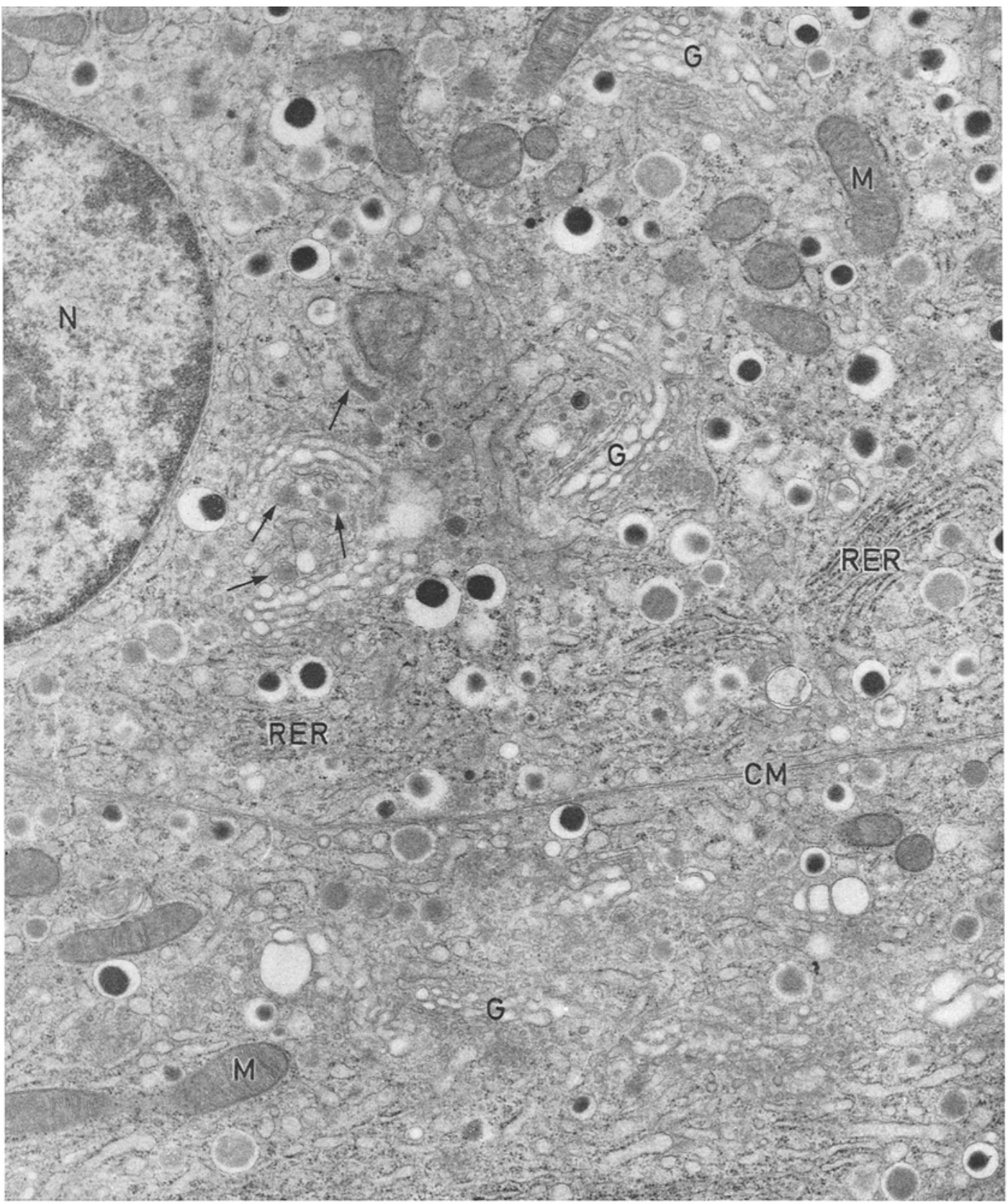

Fig. 6. Beta cells, diabetic mutant (C57BL/Ks-db/db) with early hyperglycemia. Secretory storage granules diminished and more variable in size. Rough endoplasmic reticulum increased. Golgi complex increased and dispersed with secretory material within vesicles and tubules (arrows). Cell membrane is smooth. Approximately $14250 \times$

The numerous beta cells are relatively uniform in appearance. Secretory storage granules are abundant, are almost always rounded and enclosed within loosely fitting smooth membraned sacs [Figs. 1, 2]. Occasiona] crystalline (rectangular or needle shaped) forms are visible (Fig. 2). After primary osmium fixation, the beta granules are relatively uniform in size and electron opacity and enclosed in rather spacious sacs. When either aldehyde fixative is employed, the granules are more varied in size and electron density. The less dense granules are larger and occupy a greater portion of the enveloping sacs than do the smaller granules which have greater electron opacity (Fig. 2). In most beta cells of normal mice, the rough endoplasmic reticulum is inconspicuous and the Golgi complex small. The mitochondria are elongated or circular, depending on the plane of section, but always slender and filled with numerous elosely-packed cristae mitochondriales (Fig. 1). In the occasional beta cell containing a smaller number of secretory granules, the rough en- 


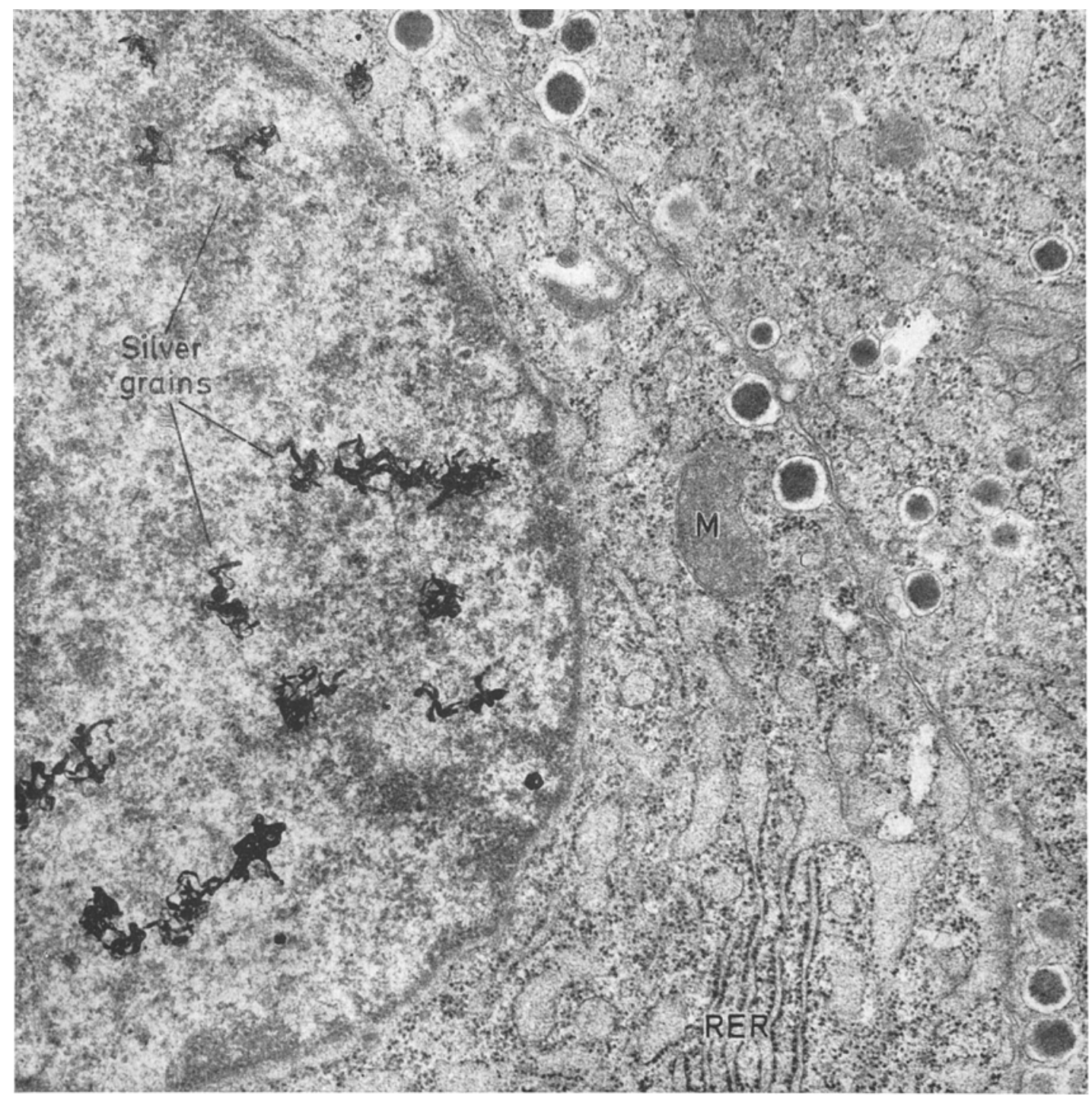

Fig. 7. Beta cells, diabetic mutant mouse with early hyperglycemia. $2 \mathrm{~h}$ after administration of thymidine- ${ }^{3} \mathrm{H}$ (Ilford L-4 emulsion, 21 days exposure). Silver grains overlying the labeled nucleus indicate the paths of the emerging beta particles. Beta secretory granules are reduced in number and rough endoplasmic reticulum increased Approximately $22000 \times$

doplasmic reticulum and the Golgi components are more prominent (Fig. 3).

The alpha cells are characterized by their peripheral location, where they form a uniform or eccentrically placed mantle separating completely or incompletely the beta cells from the surrounding exocrine pancreas. Their secretory granules are larger and more electron dense than the beta granules and are contained within tightly fitting smooth membraned sacs. There is little variation in the electron opacity of the alpha storage granules regardless of the fixative used. The rough endoplasmic reticulum is compactly organized into a number of parallel tubular profiles that are observed with frequency. Similarly, the Golgi complex is larger and better organized than its counterpart in the beta cell (Fig. 4).
Within the sparse extracellular space separating the islet cells from the fenestrated capillaries are found oceasional small non myelinated nerve endings, a rare collagen fibril and the attenuated basal lamina of the capillary (Figs. 1, 4).

The small pancreatic ducts are in close proximity to, but almost always external to the normal islets. The single layer of flattened cuboidal epithelial cells are not distinguished by any evidence of a differentiated structure: there are no secretory granules and no regularly occurring cilia. The luminal cell surfaces, however, possess a moderate number of small slender microvilli. In immediate contact with the abluminal surface is a well-formed basal lamina and beyond this a dense layer of fibrocollagen which merges with the adjacent interstitial tissue (Fig. 5). 


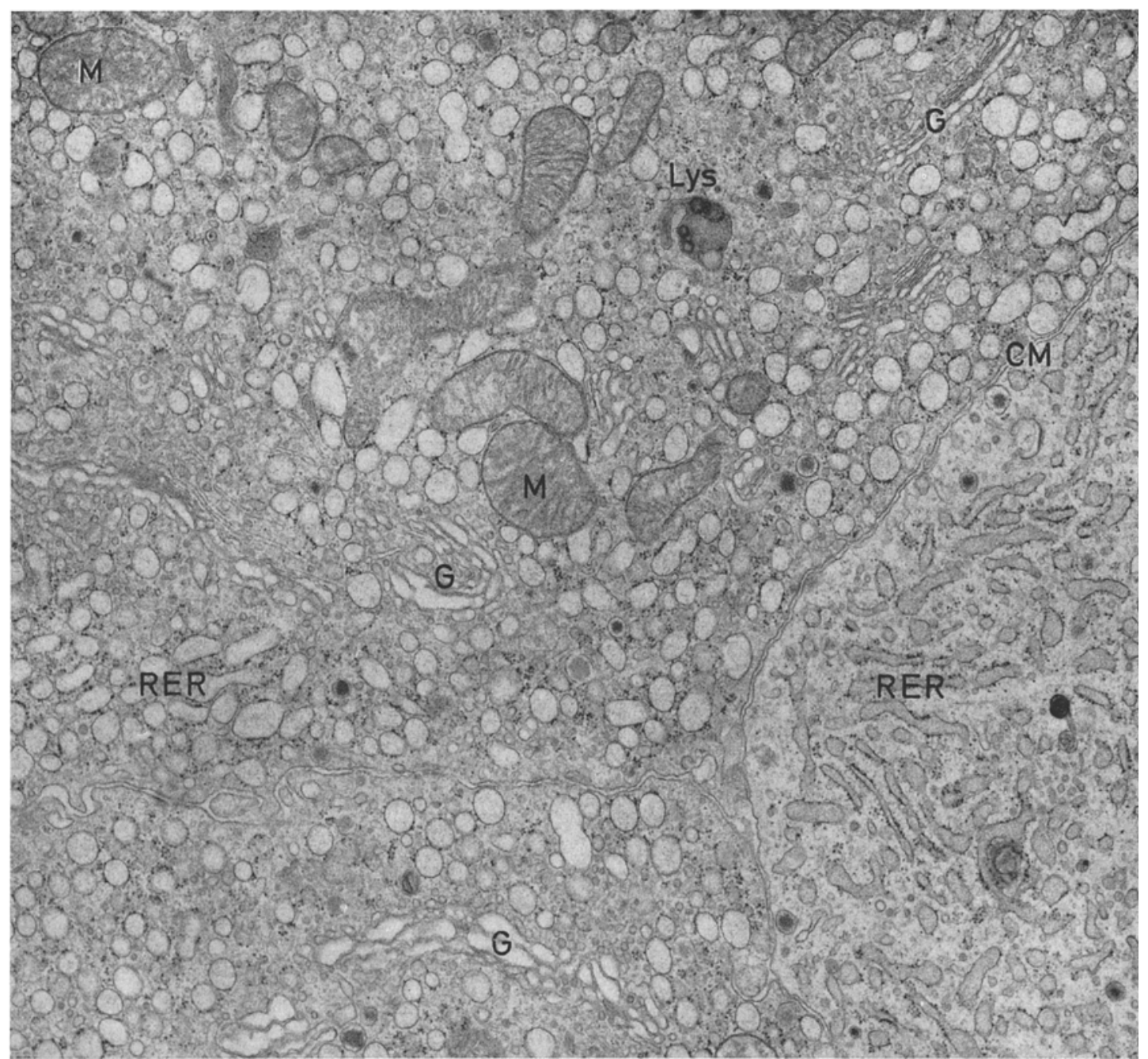

Figs. 8 and 9. Beta cells, diabetic mice with established hyperglycemia: Degranulation is more advanced. Remaining secretory granules are small. Increased rough endoplasmic reticulum is tubular (Fig. 8) and vesicular (Figs. 8 and 9). Mitochondria are enlarged and numerous, Osmium tetroxide. Approximately $14250 \times$

\section{Diabetic mutants}

Pre-hyperglycemic and early hyperglycemic mice. The beta cells of prehyperglycemic (BG $<120 \mathrm{mg} / 100 \mathrm{ml}$ ) mutants can not be distinguished morphologically from those of the normal mice without employing radioautography [9]. However, in the presence of early hyperglycemia (BG $130-200 \mathrm{mg} / 100 \mathrm{ml}$ ) beta cell structure reveals the following modifications: the rough endoplasmic reticulum is increased in quantity and numerous tubular and vesicular profiles are visible; the Golgi complex is enlarged and its components more dispersed throughout the cytoplasm; mitochondria are more numerous and moderately increased in size (Fig. 6). At this time in the course of the syndrome the recognition of partial beta cell degranulation by light and electron microscopy is possible.

The electron microscopic radioautographs reveal that virtually all of the islet cells with labeled nuclei are beta cells (Fig. 7). Only a rare leucocyte and cap- illary endothelial cell are labeled. Although sections were selected with labeled nuclei situated at the periphery as well as at the interior of the islet, all of the 12 labeled endocrine cells examined are beta cells, using the fine structural criteria listed above. Labeled alpha cells are not observed.

\section{Mice with established hyperglycemia}

1. Intact beta cells. In the presence of established hyperglycemia $(\mathrm{BG}>200 \mathrm{mg} / 100 \mathrm{ml})$ light and electron microscopic evidence of beta cell degranulation is striking. There is further expansion of the rough endoplastic reticulum and a prominent increase in the size of the Golgi complex. Formerly, a small compact organelle, the Golgi elements are now widely dispersed throughout the cell and frequently contain electron opaque material and small granules within tubular and vesicular profiles. The reduced number of secretory storage granules are more varied in size and electron 


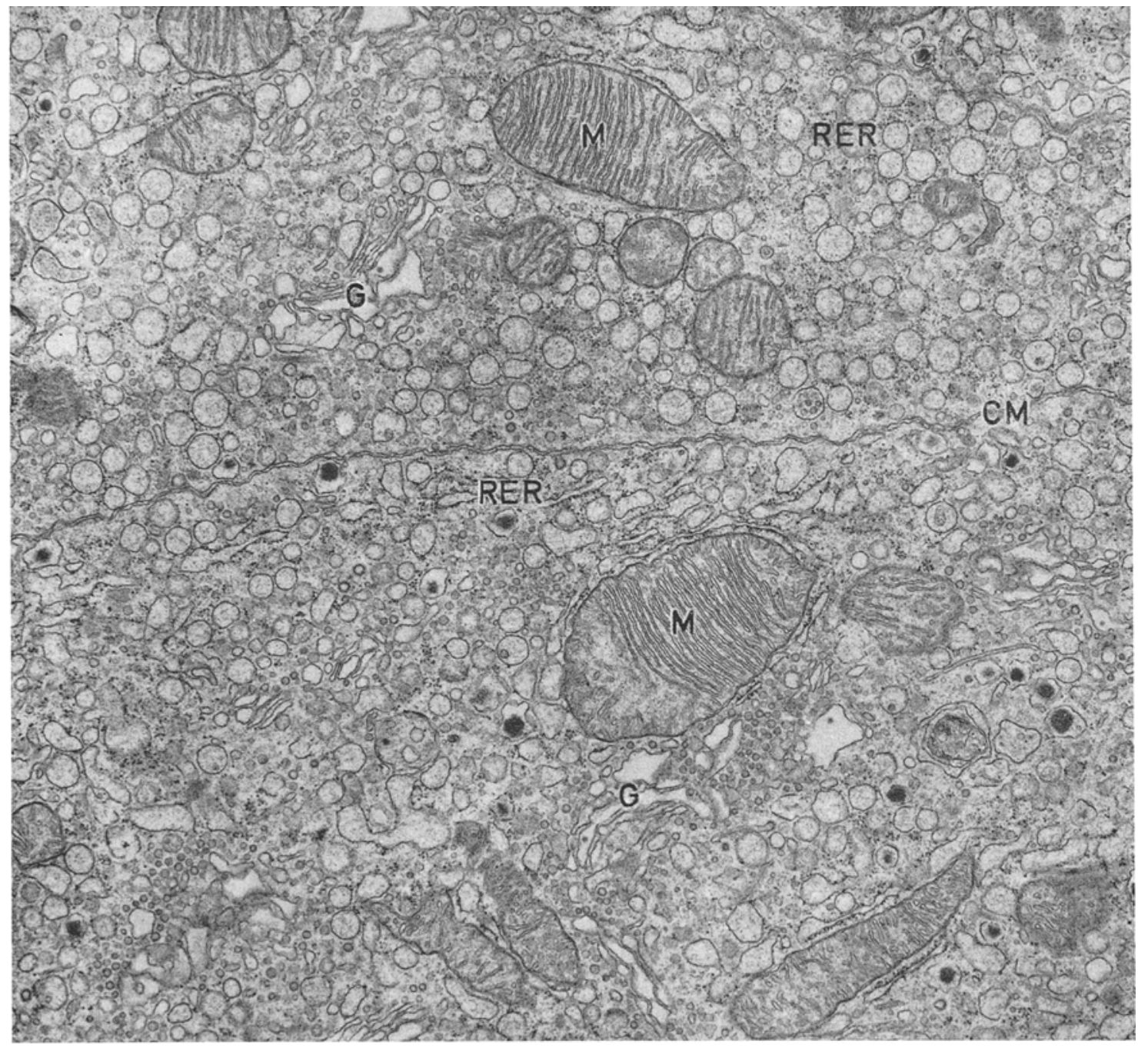

Fig. 9

opacity, with a relatively larger number of small granules visible. Their location within the cell is haphazard with no apparent concentration at the cell surface membranes. The latter show no apparent increase in surface irregularity nor any increased number of viliform projections. In contrast with the uniformly small and slender mitochondria of the normal mice and prehyperglycemic mutants, the mitochondria of animals with established hyperglycemia are increased in number and quite varied in size and shape. Many extremely large and bizarre shaped mitochondria are visible, all filled with numerous closely packed cristae mitochondriales (Figs. 6, 8, 9).

2. Necrotic beta cells. Beta cells undergoing degeneration and necrosis are not identified by light microscopy in conventional paraffin or in 1 micron epon sections. They are identified by electron microscopy, and infrequently, unless animals are examined during the early stage of the syndrome, when blood glucose is greater than $200 \mathrm{mg} / 100 \mathrm{ml}$ and increasing rapidly. Necrotic or degenerating cells have no characteristic location within the islet, occurring at random, without apparent preference for areas adjacent to capillaries nerve endings, ducts, etc. Individual cells, less commonly a pair of cells, are affected, with no evidence of groups of contiguous cells or an entire islet undergoing necrosis at one time.

The following alterations in cells undergoing necrosis are observed in islets, regardless of the method of fixation. The earliest or minimally involved cells possess a moderate number of lysosomal structures and small myelin figures scattered amongst the cytoplasmic organelles (Fig. 10). In other cells, the lysosomes are larger and may incorporate portions of the rough endoplasmic reticulum, small vesicles and mitochondria, hence may be designated autophagosomes (Fig. 11). Still other cells reveal, in addition to the above, a clumping together of cytoplasmic elements, with a coarseness of individual components due to increased electron opacity (Fig. 12). Furthermore, there are cells with pyknotic nuclei in which the cytoplasmic organelles are in such disarray and so electron opaque so as to be virtually unrecognizable (Fig. 13). Finally, fragments of necrotic cells are seen within the inter- 


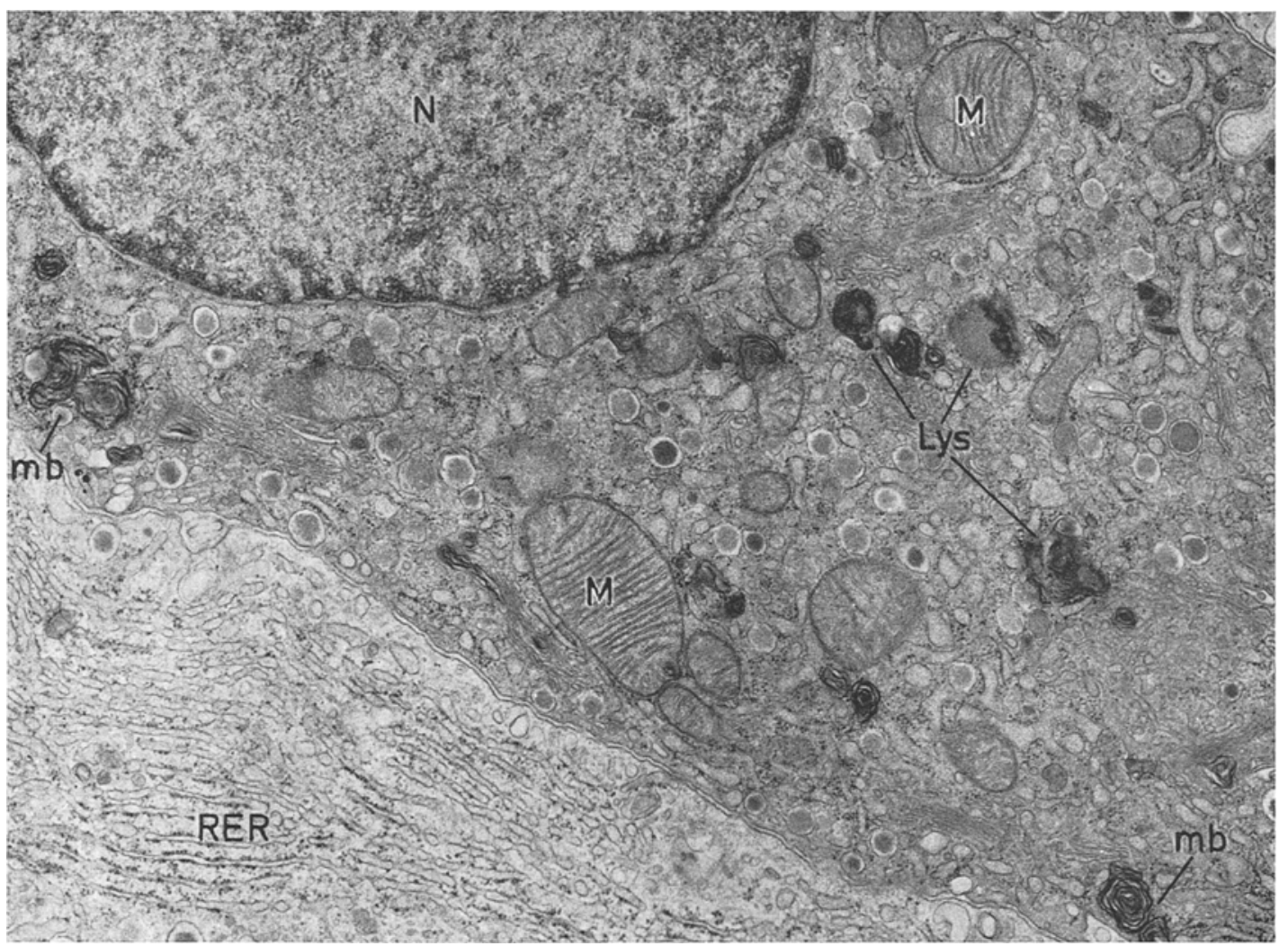

Fig. 10. Beta cells, diabetic mouse with established hyperglycemia, showing evidence of degeneration. Many myelin figures and lysosomes are visible. Adjacent beta cell reveals evidence of enhanced protein synthesis. Approximately $14250 \times$

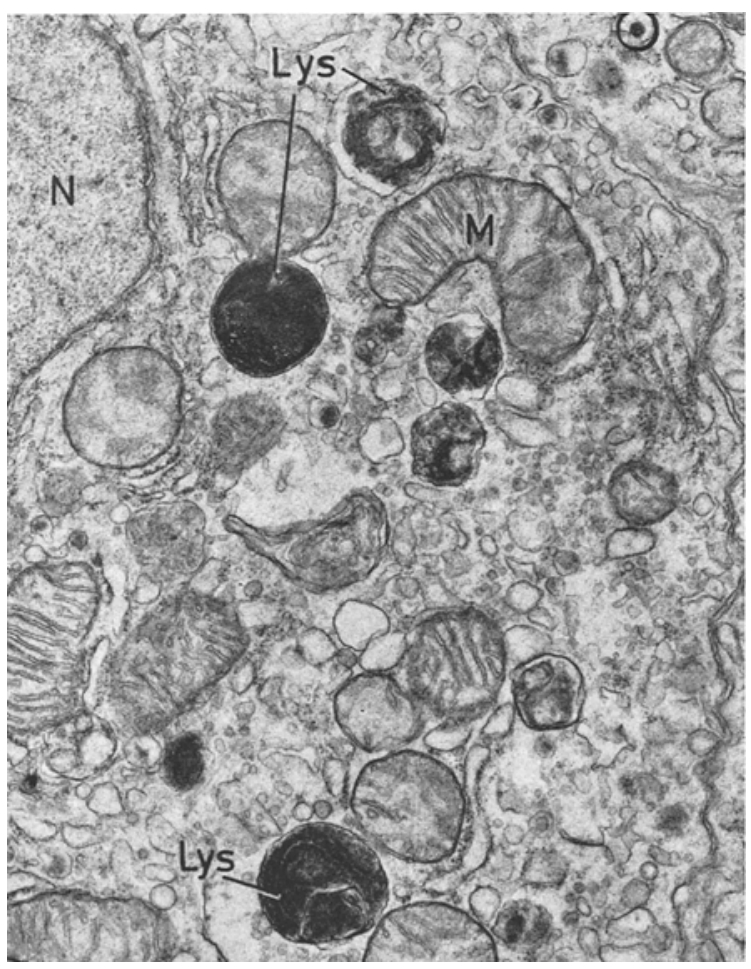

stitium and also within presumed phagocytes (Fig. 14).

Of great interest is the observation of particles of consistent appearance and dimension in some intact and numerous necrotic beta cells, as well as in a rare alpha cell. These particles are spherical, have an overall outer diameter of approximately $1000-1100 \AA$ and a core of approximately $600-650 \AA$. The inner dense core is surrounded by a membrane and is well demarcated from the outer less compact area, which may not be membrane limited and is often not sharply delineated from the surrounding cell (Figs. 11, 12). The particles are consistently found in the cell cytoplasm; no nuclear involvement is apparent. They are observed in vesicular profiles of the rough endoplasmic reticulum, and commonly in membrane lined vesicles devoid of ribosomes. Otherwise normal appearing beta cells may harbor one or a number of these particles. The more heavily involved cells usually reveal the stigmata of degeneration and necrosis described above, as well as areas of apparent cytoplasmic lysis, wherein the organelles have apparently been replaced by a finely

Fig. 11. Beta cell, diabetic mouse with evidence of degeneration. Large lysosomes containing fragmented organelles (autophagasomes). A virus-like particle is encircled. Osmium tetroxide. Approximately $14250 \times$ 


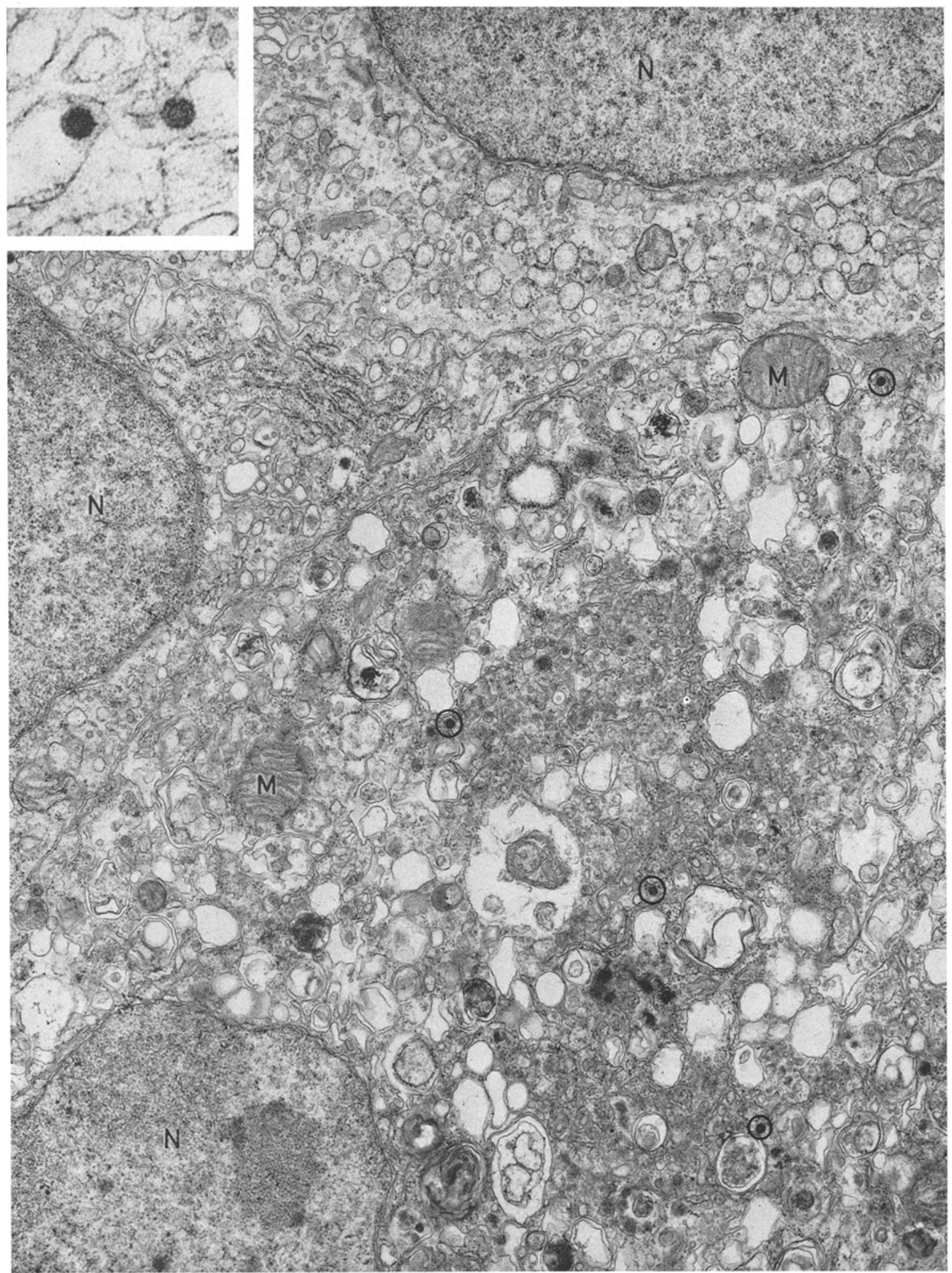

Fig. 12. Portions of several beta cells, diabetic mouse. The architecture of the cell which occupies the major portion of the micrograph is virtually unrecognizable. Several secretory granules and mitochondria are visible. Autophagasomes, lysed and clumped cytoplasmic elements and virus-like particles encircled) are present. Osmium tetroxide. Approximately $14250 \times$. Insert reveals high mangnification viewi of virus-like particles: the inner cores are $600-650 \AA$ and the overall diameters $1000-1100 \AA$. Approximately $48400 \times$ 


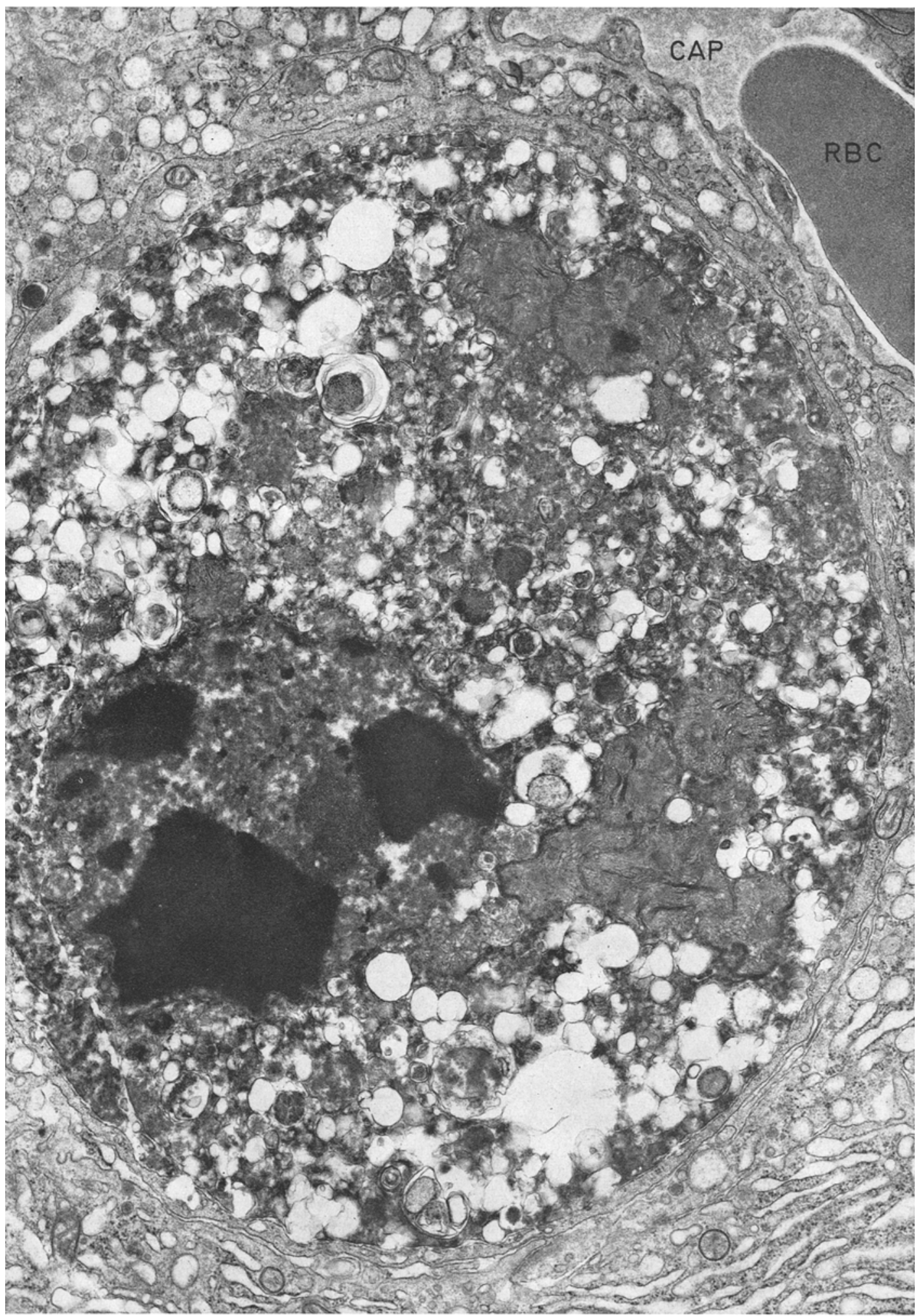

Fig. 13. Necrotic beta cells, diabetic mouse with established hyperglycemia: the pylnotic nucleus and the clumped electron dense cytoplasmic components indicate cell death. Approximately $14250 \times$ 


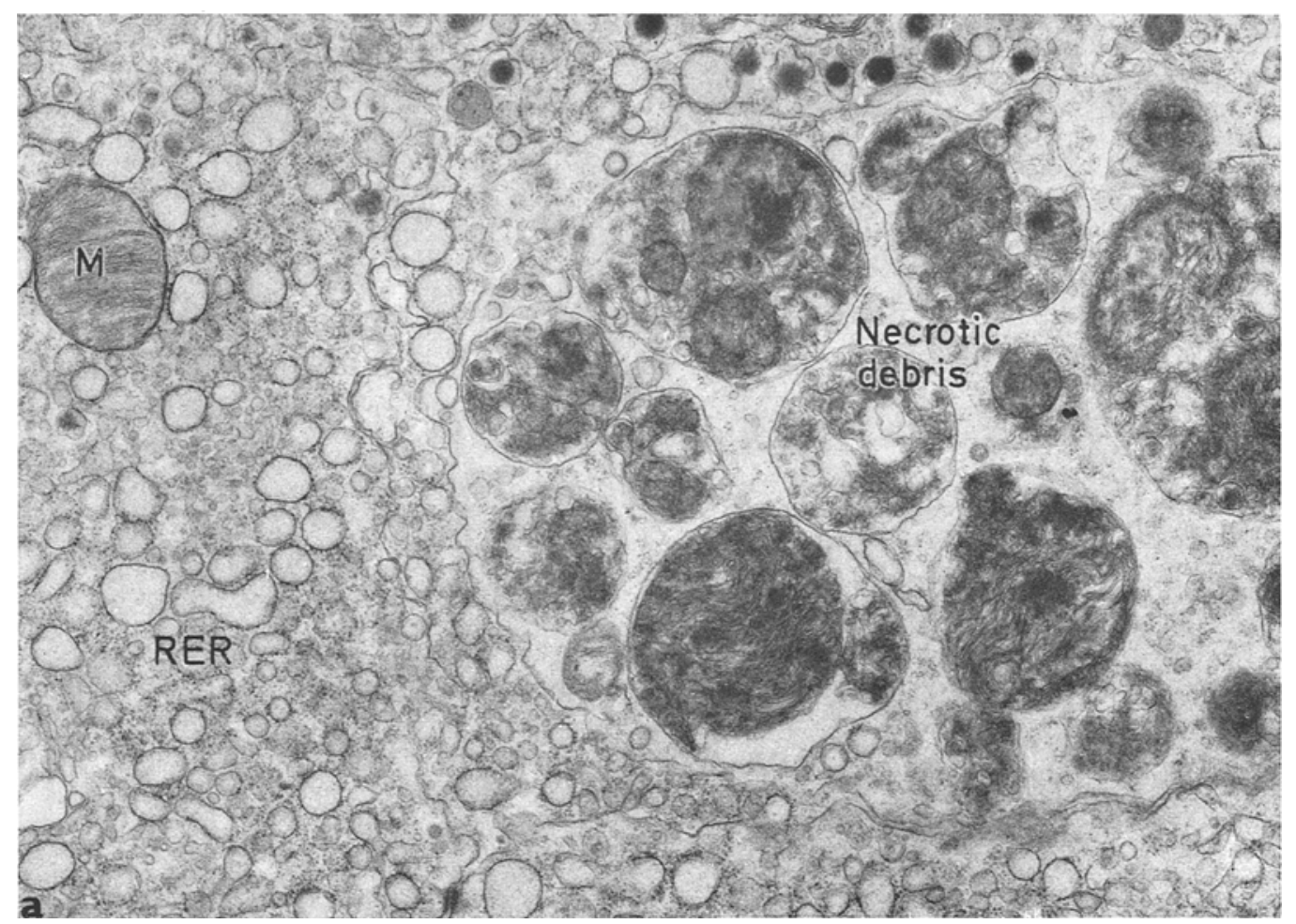

Fig. 14a. Beta cells, diabetic mutant mouse: the membrane bound remnants of necrotic cytoplasmic components are within the interstitium or within a macrophage. Portions of necrotic mitochondria and secretory granules are evident. Approximately $14250 \times$

particulate, low density material, resembling "cell sap". This last-mentioned phenomenon is more characteristic of acinar cells which may contain large numbers of these particles (see below). These particles have been identified in beta cells of many different mutants; the dimensions cited are consistent for the two methods of fixation and the three fixatives utilized. The appearance and dimensions of the particles suggest that they represent an as yet unidentified virus.

Mice with advanced hyperglycemia and in terminal stage of syndrome

Until this point our description of the pancreatic islets has been limited to mutants sacrificed relatively early in life, when the overall organization of the islets is intact. Later in the syndrome and with considerable variability from animal to animal and from islet to islet, the configuration of the islets is greatly altered.

1. Intact islets. In an occasional islet that has retained the round or oval shape and the sharp demarcation from the surrounding exocrine tissue, the peripheral - central, alpha-beta cell orientation of the normal islet is replaced by a random mixture of the 2 cell types within the islet interior (see Fig. 8 in [9]). Most islets, however, are irregular in outline and are honeycombed with small and sometimes dilated ductal structures. The reduced number of residual endocrine-islet cells are gathered in haphazard clusters with no semblance of the former orientation. Adding further to the or-

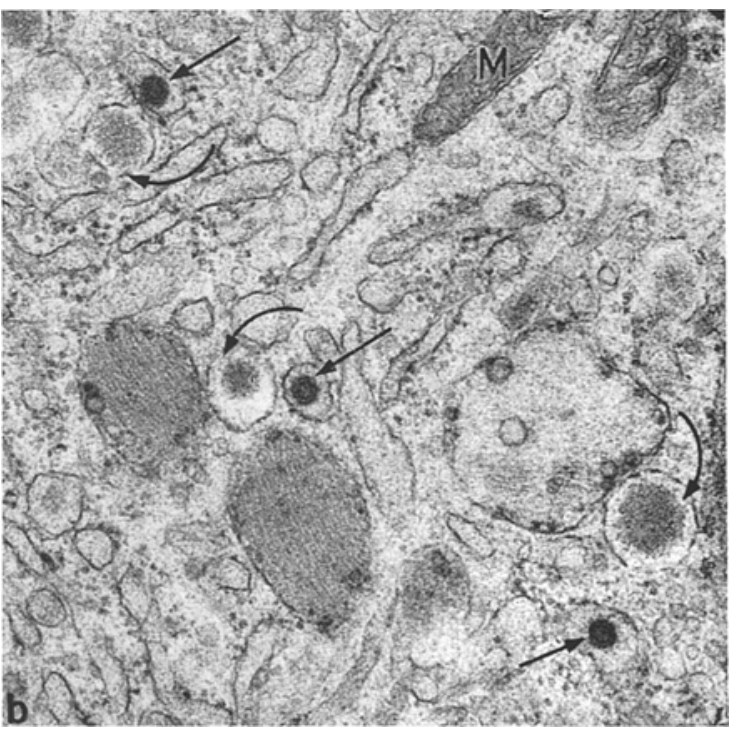

Fig. 14b. Portion of an intact beta cell, diabetic mutant mouse: virus-like bodies (straight arrows) are present within vesicular profiles of the rough endoplasmic reticulum. Beta granules (curved arrows) and oblique sections of the unidentified elongated structures (see Fig. 29). Approximately $32800 \times$

ganizational chaos, are groups of acinar cells within the islet interior, as well as an irregular network of 


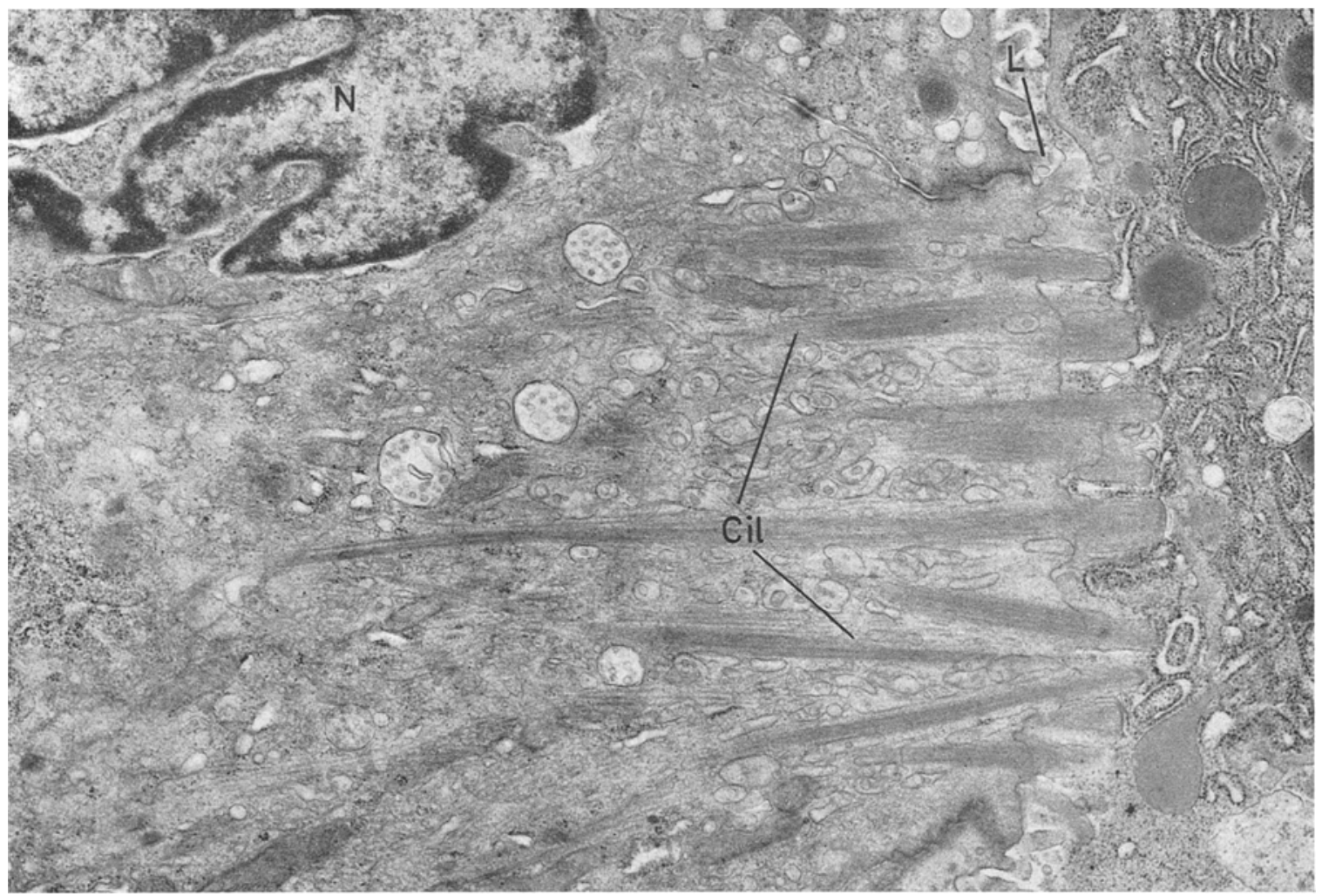

Figs. 15-21. Document the appearance of the proliferating ducts in diabetic mutant mice in the terminal stage of the syndrome

Fig. 15. Ciliated epithelial cell on the luminal surface of a collapsed duct lumen (L). A portion of an acinar cells also present. Approximately $14250 \times$

fibrocollagen which joins the islet interior with the periislet exocrine tissue (see Fig. 11 in [9]).

2. Proliferating ducts. The ultrastructure of the cells lining the newly formed ducts reveals a remarkable variability, unknown in the cells lining the small exocrine ducts adjacent to the islets of normal mice. Few cells are without evidence of structural differentiation. Infrequently ciliated epithelial cells are present, singly or in small groups of two or three (Fig. 15). Pancreatic acinar cells are observed on the luminal surface of the ducts with greater frequency (Figs. 16, 17). Most common, however, are epithelial cells containing large secretory granules which consist of a small electron dense core and a peripheral fibrillar component which is relatively electron lucent (Figs. 18, 19). These strongly resemble the secretory granules of most Paneth cells and some mucous goblet cells [17]. The mitochondria are larger than those of normal ductal cells and frequently possess electron opaque granules, of variable size, within the cristae mitochondriales (Figs. 19, 20). The luminal surface is thrown up into a number of microvilli similar in size and number to those present in normal ducts (Figs. 16-19). The abluminal surface is often in direct contact with the elusters of underlying islet or acinar cells, separated at times only by a pair of cell membranes (Figs. 16, 17,
21). Alpha and beta cells are not observed on the luminal surface of any ducts; they are always separated from the ductal lumen by one of the several types of lining cells described above (Figs. 16, 17, 21). Not infrequently, an extremely attenuated portion of the ductal cell cytoplasm separates the islet cell from the lumen, while in other instances, a well-formed basal lamina together with a layer of fibrocollagen are interposed between duct lining cells and the underlying islet cells. It is also of interest that although the ductal lining cells cited are joined to one another by well-formed junctional complexes (Figs. 15, 16, 17), only infrequent, small and incomplete desmosomes join islet cells together or to the cells lining the ductal lumina. In none of the numerous micrographs studied were transition forms between ductal lining, acinar and islet cells observed.

3. Intra-islet acinar cells. Acinar cells within the islets of diabetic animals are in frequent (Figs. 16, 17) but not exclusive association with the ductal elements. The extent to which endocrine islet cells are replaced by acinar cells is variable; islets are present with one or several acinar cells at the periphery, while there are others in which acinar cells predominate. The ultrastructure of these cells is also quite variable. Most are cytologically intact and differ from the normal only 


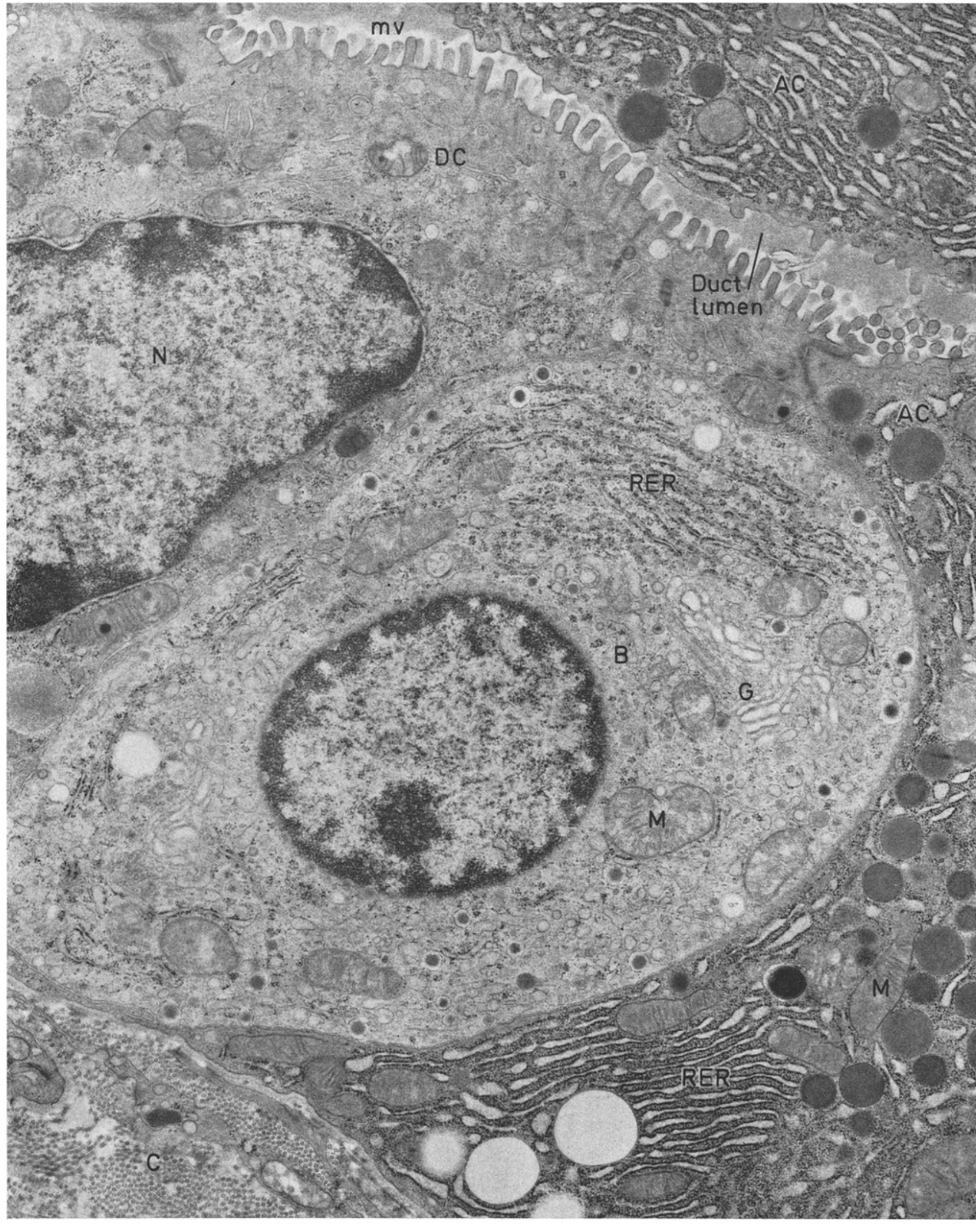

Fig. 16. The luminal surface is lined by portions of 2 acinar cells (AC) and a ductal epithelial cell (DC). The beta cell $(B)$ is not on the duct lumen. Approximately $14250 \times$ 


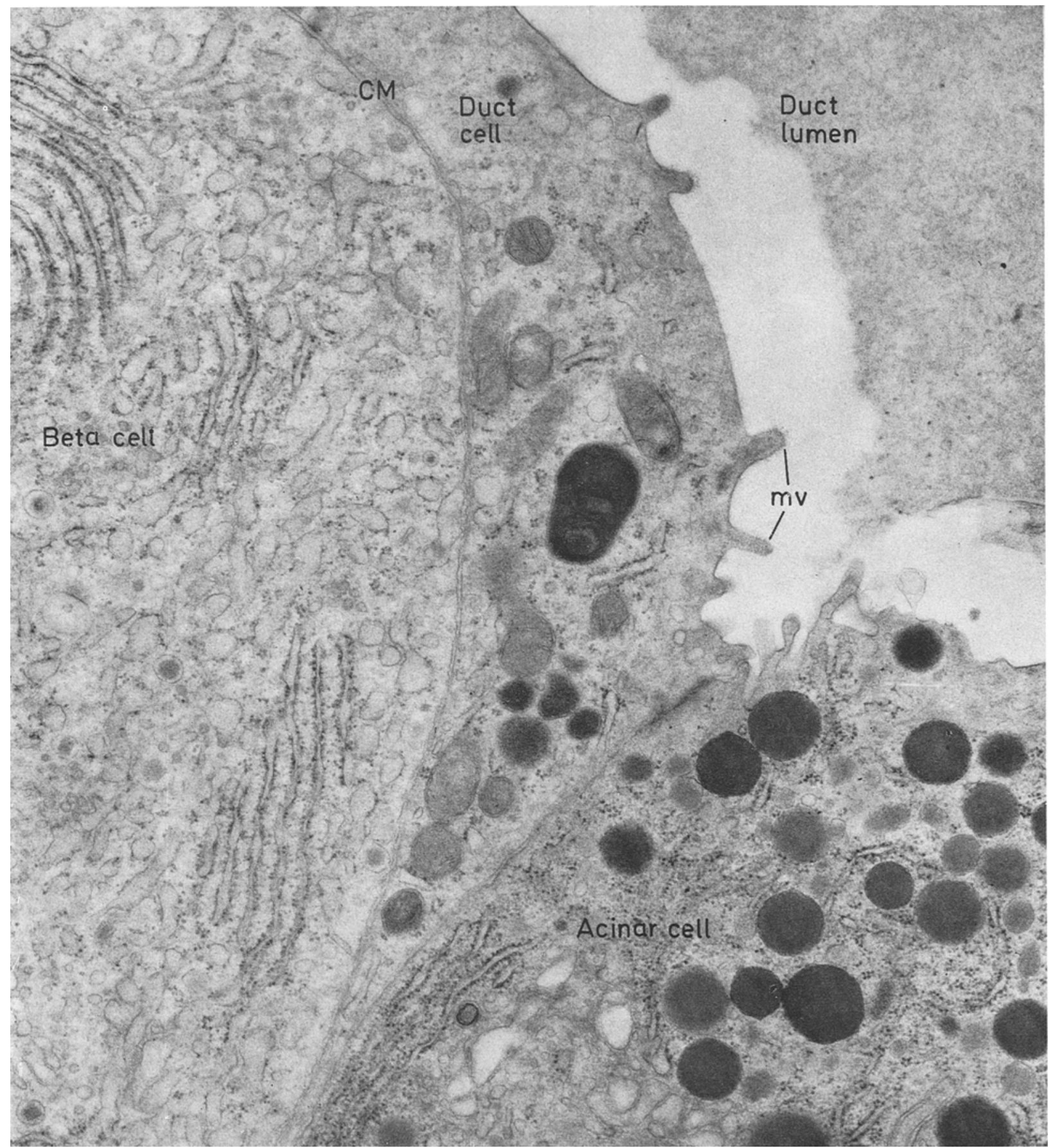

Fig. 17. Another example of a beta cell close to but not on the luminal surface of a duct. A narrow portion of a ductal cell separates the beta cell from the lumen. Approximately $22000 \times$

because of their location and the inevitable architectural distortion. (It is unclear whether all of the displaced acinar cells have access to an intercalated duct for secretory discharge). Those which are situated on the luminal surface of an intra-islet duct also are cytologically normal and appear to release their secretory product directly into the duct lumen (Fig. 17). In other acinar cells the tubular profiles of the rough endoplasmic reticulum are dilated and contain several or many spherical granules of variable size and density (Figs. 22, $23,24,25)$. The more extensively involved cells often contain membranous and amorphous aggregates of disrupted organelles (Figs. 23, 25). Areas of apparent intracellular lysis are noteworthy (Figs. 26, 27), where- 


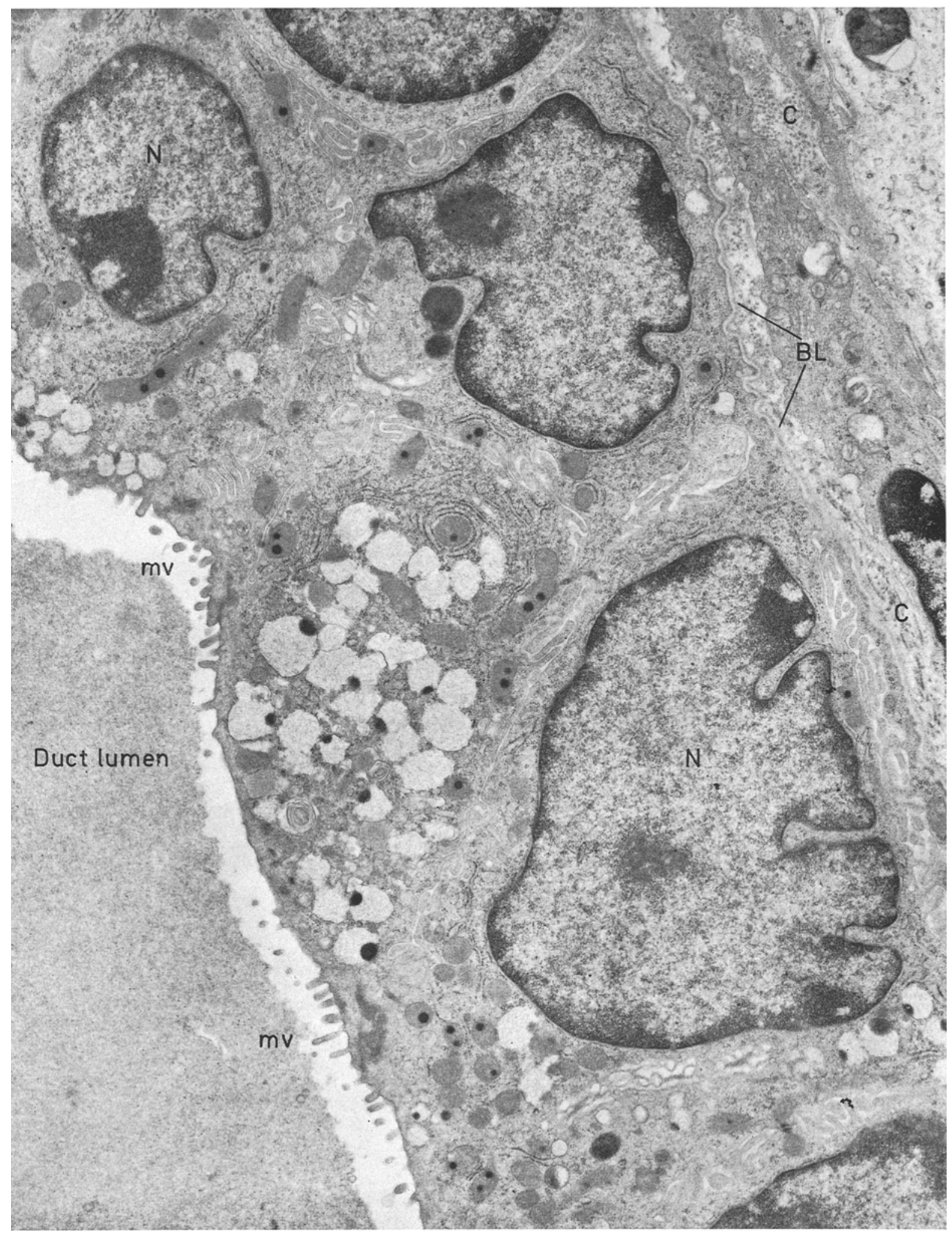

Fig. 18. Survey micrograph of a proliferating duct lined by secretory epithelial cells resembling intestinal paneth cells and mucous cells. The lumen contains a dense secretory product. Microvilli are on the luminal surface. A well defined basal lamina and collagen fibrils delimit the abluminal surface of the cells. Approximately $9500 \times$ 


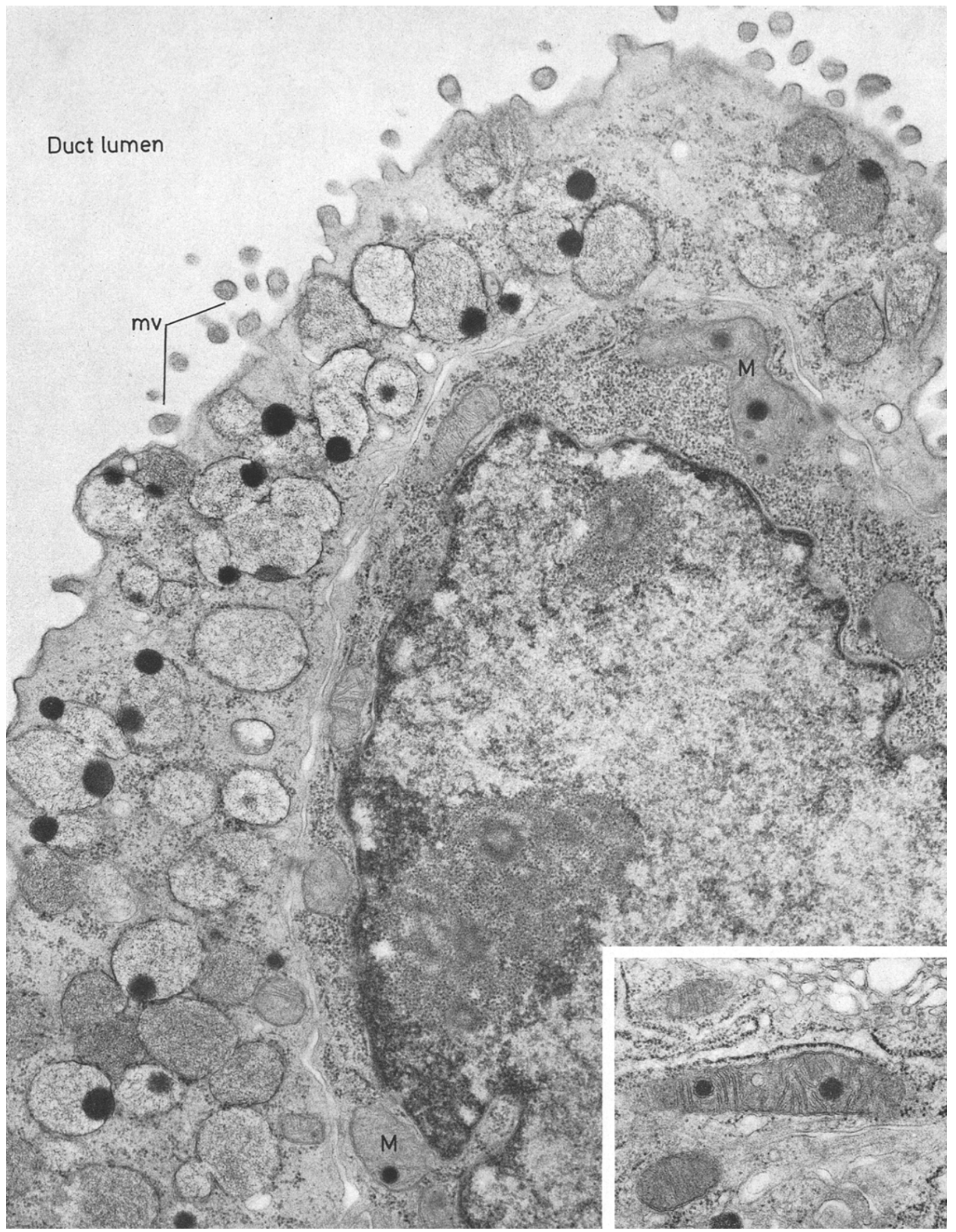

Fig. 19. Higher magnification of ductal epithelial cell: secretory granules consist of an electron dense eccentric core and a more lucent fibrillar component. The mitochondria possess dense granules (see Fig. 20). Approximately $22000 \times$ Fig. 20. Mitochondrion from ductal epithelial cell revealing electron dense granules within the cristae. Approximately $22000 \times$ 


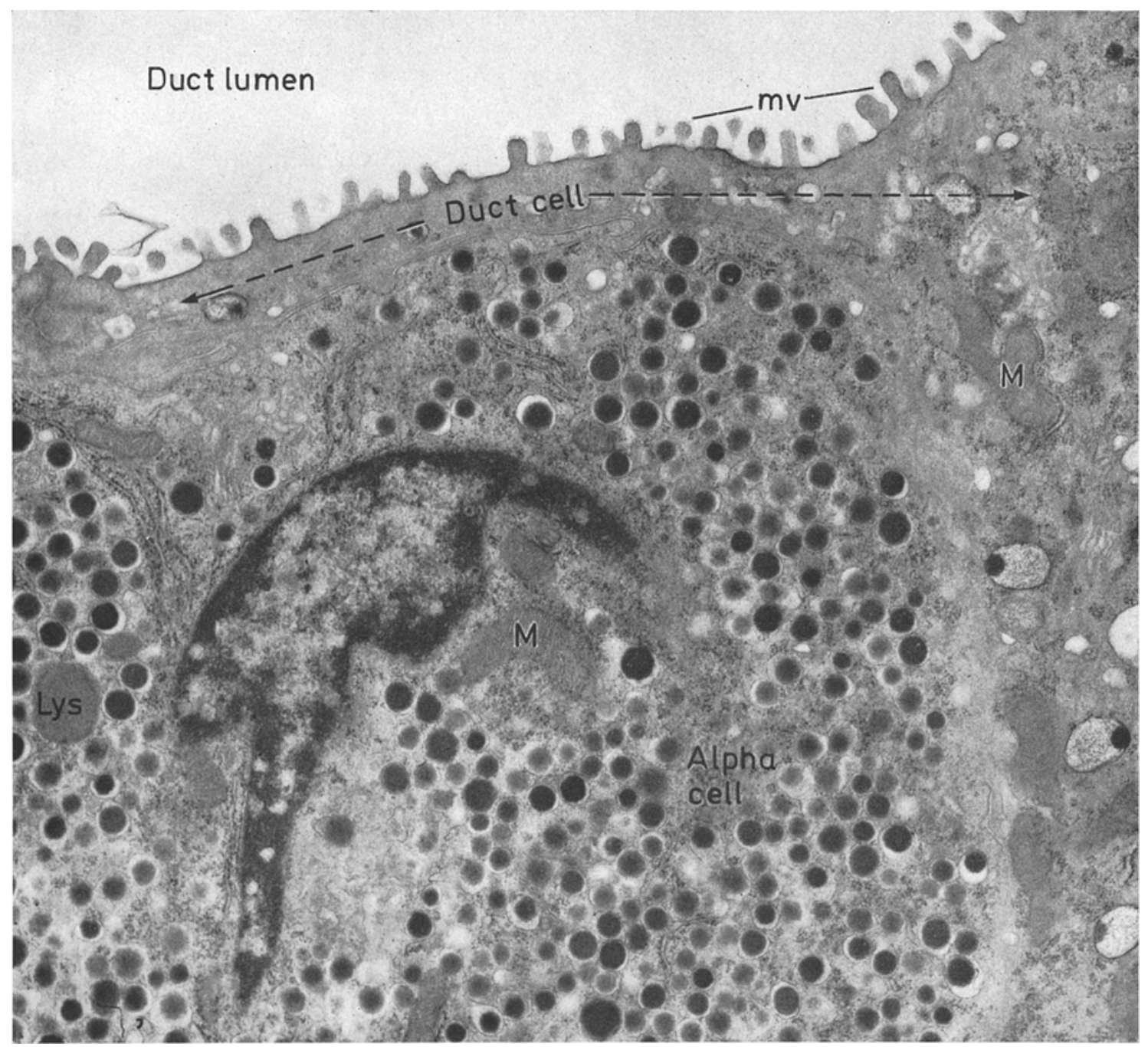

Fig. 21. A narrow portion of a ductal epithelial cell separates the alpha cell from the lumen. This narrow cel process could not be resolved by light microseopy. Approximately $14250 \times$

in vesicular remnants of the rough endoplasmic reticulum containing the spherical granules are surrounded by a structureless aggregate of low electron density in which occasional ribosomes, mitochondria and vesicles are recognized. Almost always present in these cells are the "virus-like" particles described in the necrotic and intact beta cells (Figs. 25,28 ).

4. Beta cells. The major cytologic alterations within beta cells of mice with advanced hyperglycemia and in the terminal syndrome are those already described for the earlier periods of hyperglycemia. Additional findings during the later stages include the presence of many bizarre and giant mitochondria (Fig. 29) and a number of unidentified elongated structures, often several micra in length and having an inner structure of compact longitudinally arranged microtubules or fibrils (Fig. 30). More significant perhaps is the spatial realignment of beta cells within islets which may have a normal configuration or may be permeated by small ducts and fibrous septae as described above. A random section of such an islet reveals irregularly shaped beta cells occurring singly or in small clusters. They are at times surrounded by fibrocollagen, are adjacent to acinar, alpha or new ductal cells, but neither in a state of transition with duct, alpha or acinar cells, nor forming the luminal surface of the ducts.

5. Alpha cells. The alpha cells are altered predominantly by changes in location within the islets, best appreciated by light microscopy [9]. There are however no consistant or convincing ultrastructural alterations noted among the cell organelles. Although occasional lysosomal structures are visible (Fig. 31), these are also present in normal mice. There is no compelling evidence of granulolysis [15]. These comments concerning the alpha cells of the diabetic mutants are pertinent for this cell component in animals at all stages of the syndrome. 


\section{Discussion}

Normal mice and prehyperglycemic mutants

The findings reported above indicate that there were no ultrastructural differences between the pancreatic islets of normal mice $(\mathrm{C} 57 \mathrm{BL} / \mathrm{KsJ})$ and diabetic mutants $(\mathrm{C} 57 \mathrm{BL} / \mathrm{Ks}-d b / d b)$, prior to the onset of carbohydrate intolerance. On the basis of the morphologic appearance alone, and without the aid of radioautography, one could not predict which islets belong to animals with the $d b$ genes; it follows, that there were no recognizable preexisting structural in the endocrine pancreas of the mutants. The findings also indicate that these islets could not be distinguished from those of other inbred, hybrid and random bred. mice $[12,11]$. at the cell surfaces, suggested again that the Golgi derived vesicles and tubules have a role in the secretion of nongranular insulin during times of sustained hyperglycemia [7].

The rate of beta cell replication was very high and probably reached a maximum during the early phase of hyperglycemia (blood glucose $130-200 \mathrm{mg} / 100 \mathrm{ml}$ ) $[9,1]$. The inability to identify the beta cells which were preparing for mitotic division, without the use of radioautography, the presence of labeled nuclei (after thymidine ${ }^{3} \mathrm{H}$ administration) within normal appearing beta cells and the presence of beta granules in cells during mitosis [8], all strongly supported the belief that in adult mice, beta cells beget other beta cells. There was no population of undifferentiated precursor

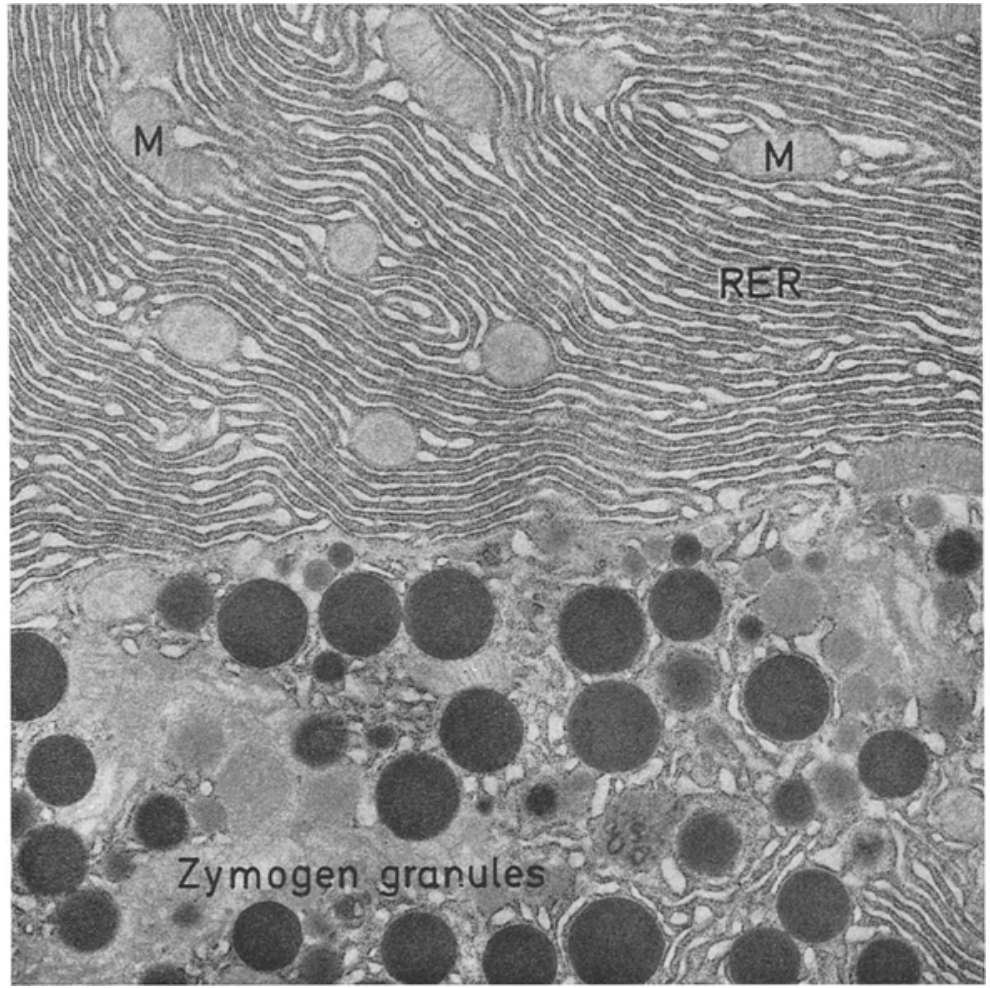

Fig. 22. Portions of 2 normal panereatic acinar cells. Note the compact parallel tubular profiles of the rough endoplasmic reticulum and the large electron dense zymogen granules. Approximately $14250 \times$

\section{Diabetic mutants}

Beta cells. In association with increased blood glucose levels, the familiar cytologic evidence of increased function were invariably present. Hence, the magnitude of the beta cell degranulation, the increase in rough endoplasmic reticulum, the expansion of Golgi structures and the increased numbers and size of $\mathrm{mi}$ tochondria were directly related to the degree of glycemic elevation $[12,11,10,14,16]$. The very large and often bizarre configuration of the mitochondria resem. bled alterations in the Wellesley and Swiss-Hauschka mice $[12,11]$, and have not been reported in other spontaneously diabetic species. The enlarged Golgi complex and the absence of discharging beta granules cells, within pancreatic islets of adult mice, which served as the progenitors of new beta cells.

The evidence of beta cell destruction cited above is quite unique for several reasons. It was observed early in the syndrome at a time when blood glucose levels were increasing most rapidly. Unlike other examples of beta cell necrosis in spontaneous diabetes $[10,14]$, or in growth hormone induced diabetes [19] there was no associated intracellular accumulation of glycogen. Certainly, the most unusual and unexpected finding, was the presence of significant numbers of particles, having a consistent size and appearance and resembling viruses, [? C type particles]. In so far as the identification of the viruses, and their role in the etiology of beta 


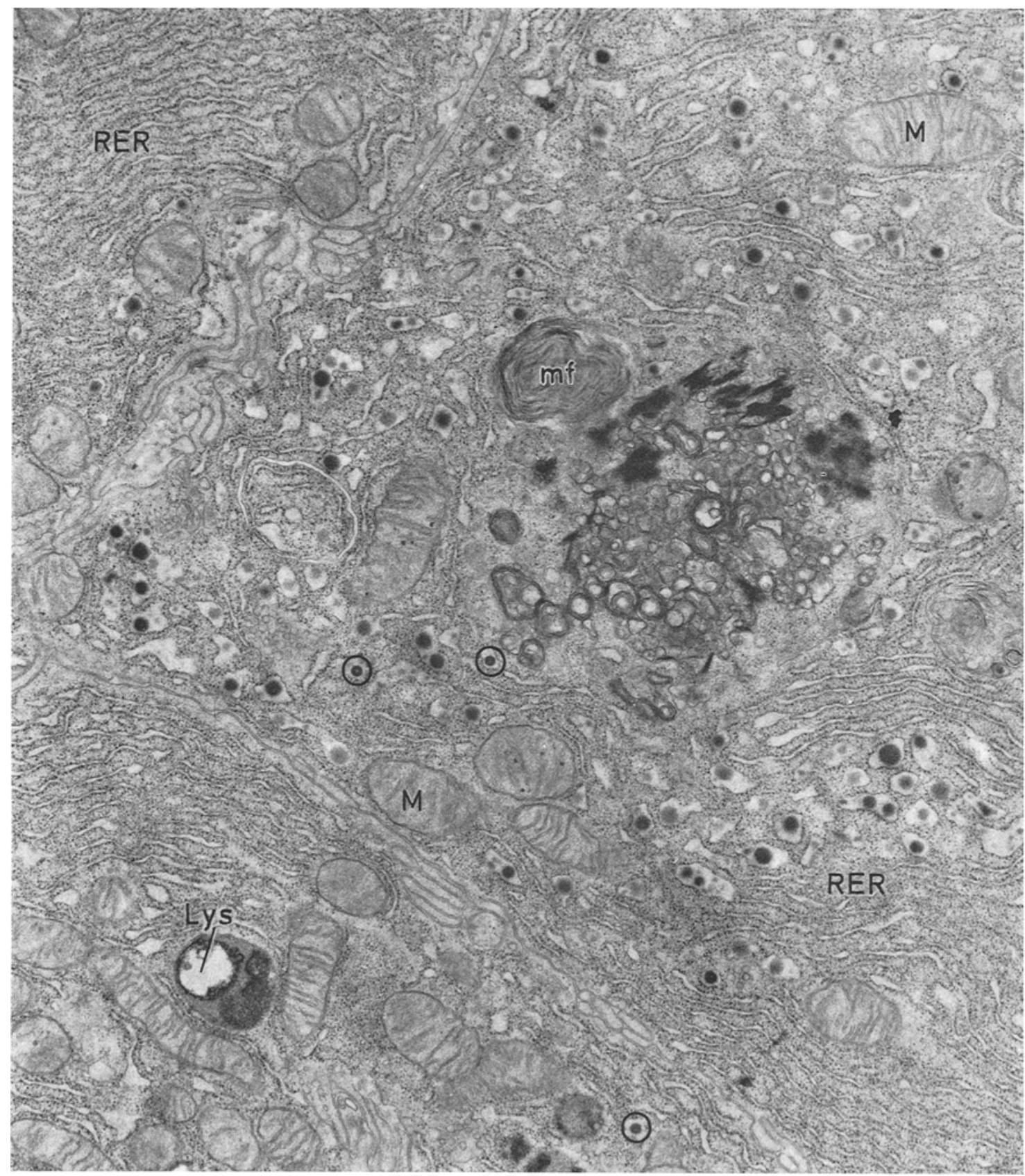

Figs. 23-28. Depict the appearance of the intraislet acinar cells which are undergoing degeneration and contain many virus-like particles

Fig. 23. The centrally located acinar cell contains a large aggregate of membranous and electron dense debris. Dilated profiles of the rough endoplasmic reticulum contain dense spherical granules. The virus-like particles are encircled. Approximately $14250 \times$

cell necrosis have not yet been established, one can not exclude the possibility that they arrived on the scene only after other and etiologic factors had already damaged the beta cells. In support of this explanation is the presence of these particles, albeit in very small numbers, within a rare alpha cell, in the absence of cell damage. On the other hand, the presence within beta cells of the characteristic cytoplasmic lysis that is commonly associated with viral infection, and the degenerative changes, also with cytoplasmic "lysis", within intra-islet acinar cells containing these particles, can be cited as evidence in favor of a viral agent having cytotoxic potential. Recently a diabetic syndrome was produced in mice with a modified coxsackie virus having the capability of inducing acinar as well as beta cell necrosis $[3,4]$. 


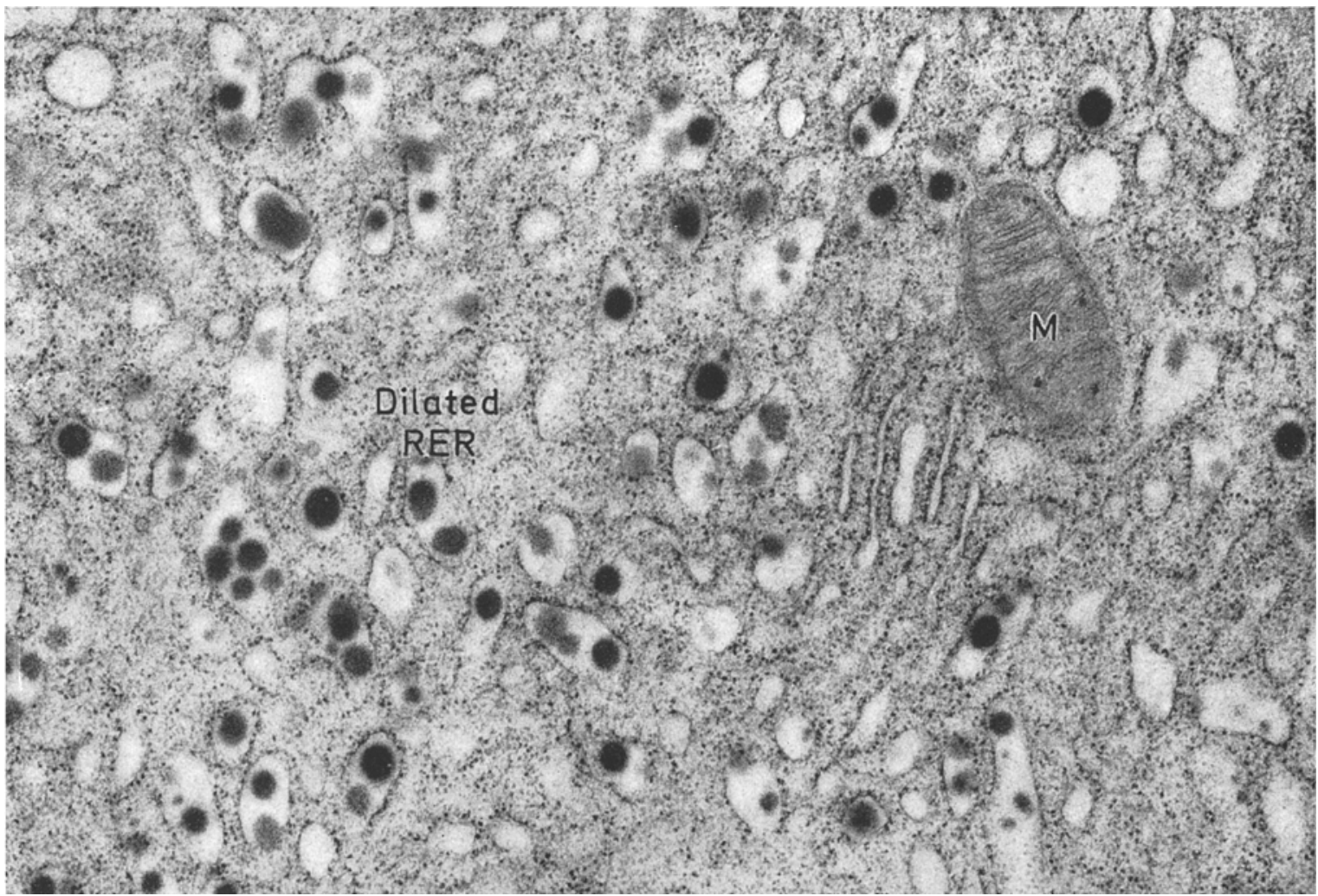

Fig. 24. Dilated tubules of the rough endoplasmic reticulum at higher magnification. Their size and appearance is variable. Approximately $22000 \times$

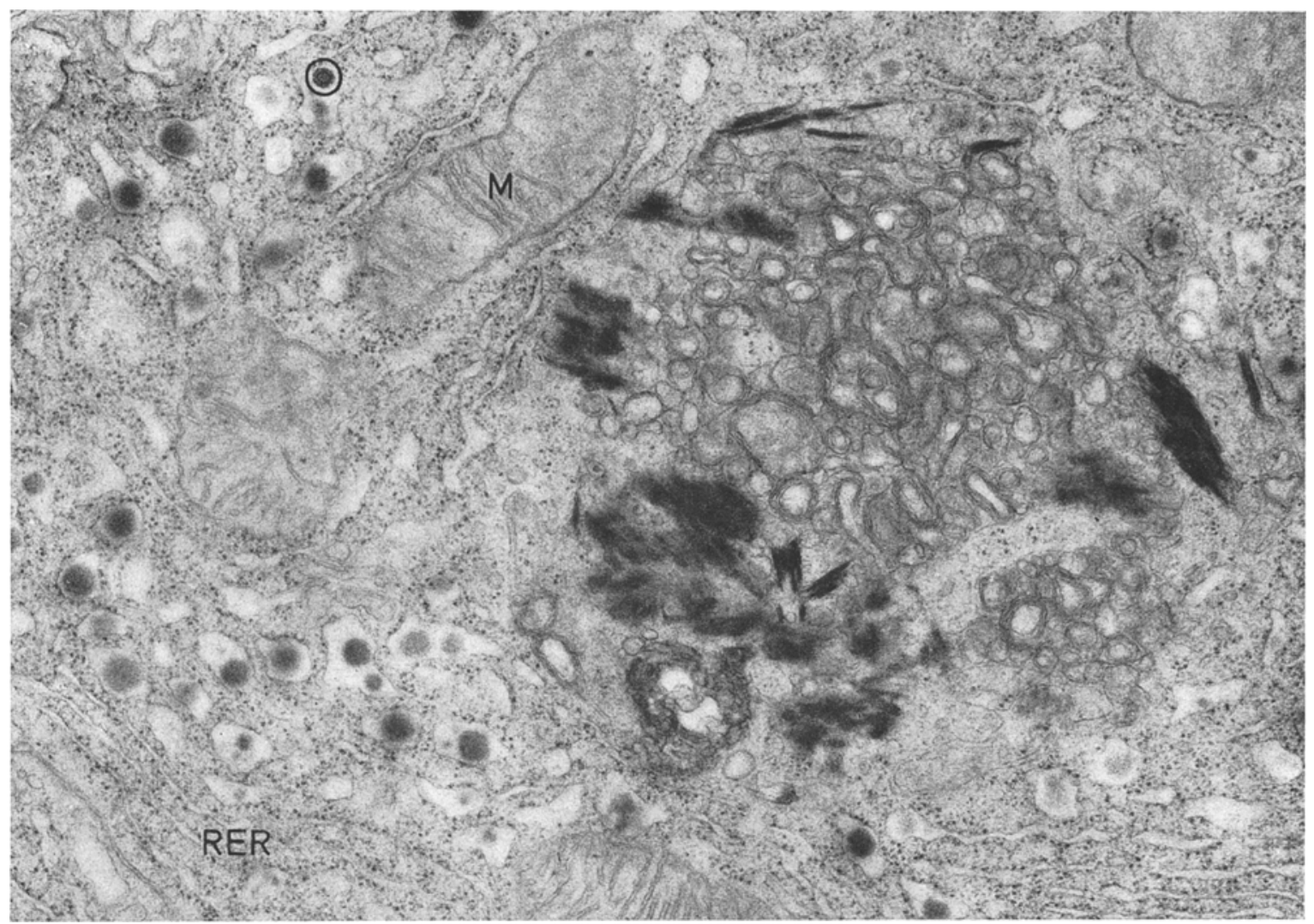

Fig. 25. Acinar cell degeneration. The membranous and proteinacious components at higher magnification. A virus-like particle is encircled. Approximately $22000 \times$ 

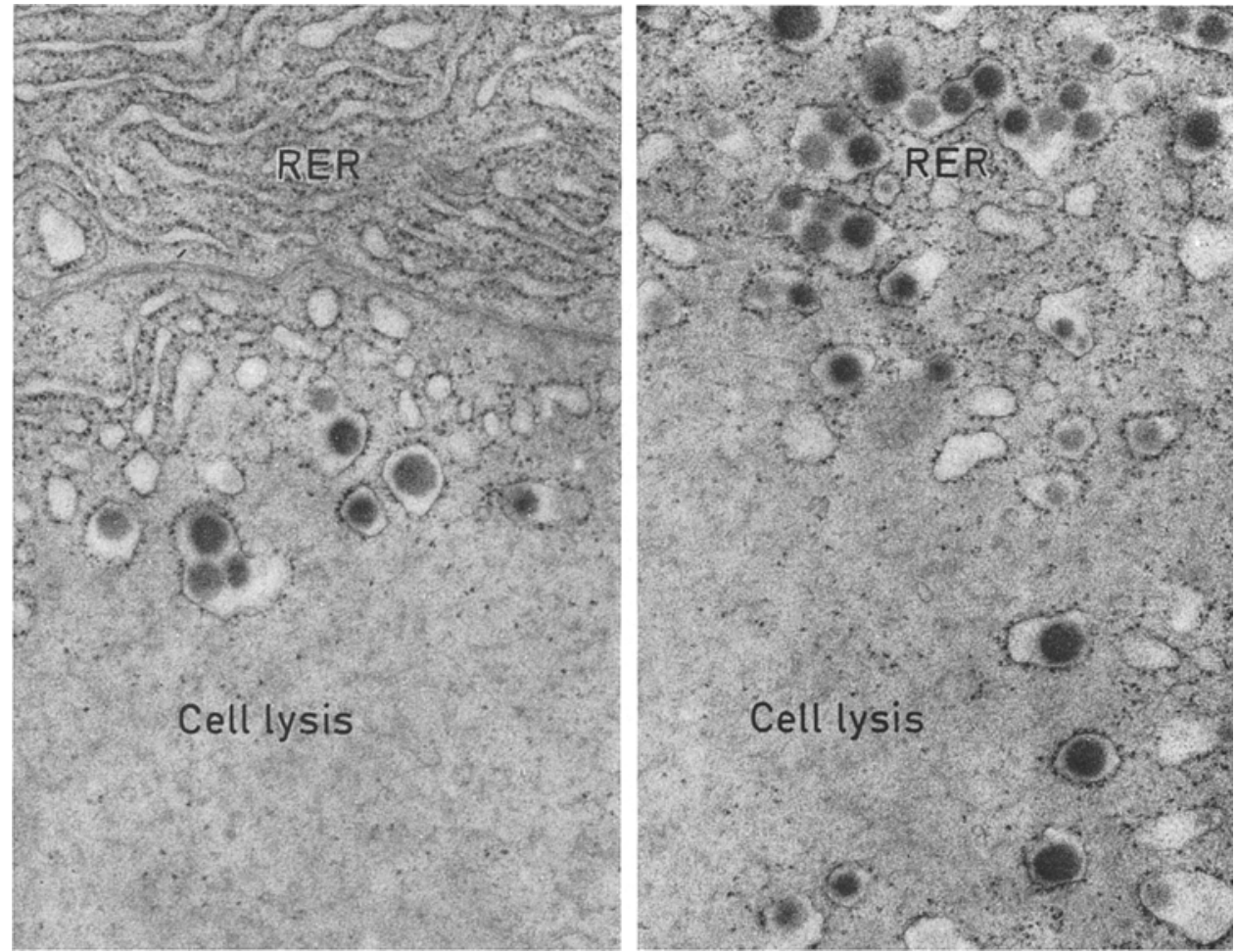

Figs. 26 and 27. Portions of acinar cells with evidence of cytoplasmic lysis. Remnants of cell structure are visible. Vesicular profiles of the rough endoplasmic reticulum contain spherical dense bodies. Approximately $22000 \times$

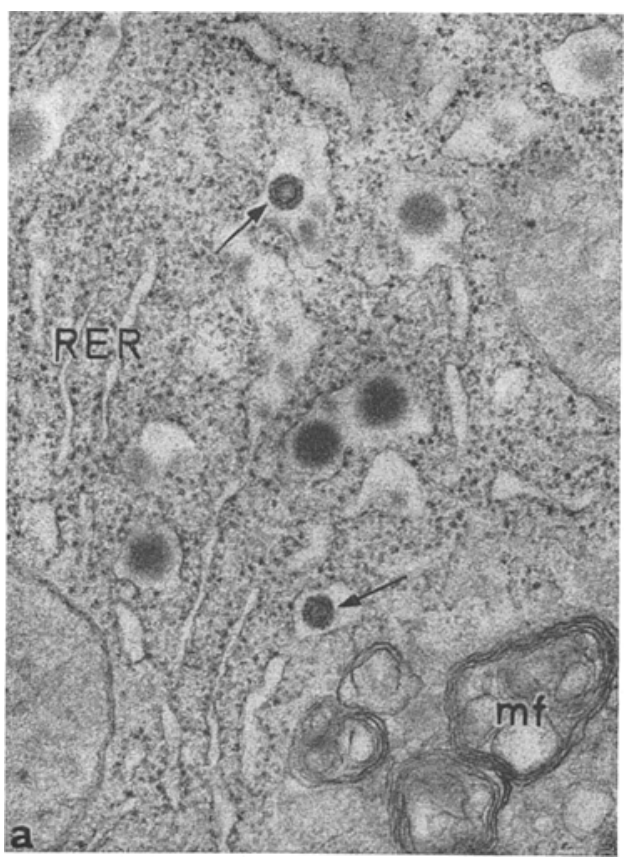

The intraislet and periislet inflammation and fibrosis were believed to be secondary and nonspecific reactions to beta cell necrosis.

Alpha cells.The findings reported above indicate that this cell type played no role or only a minor role

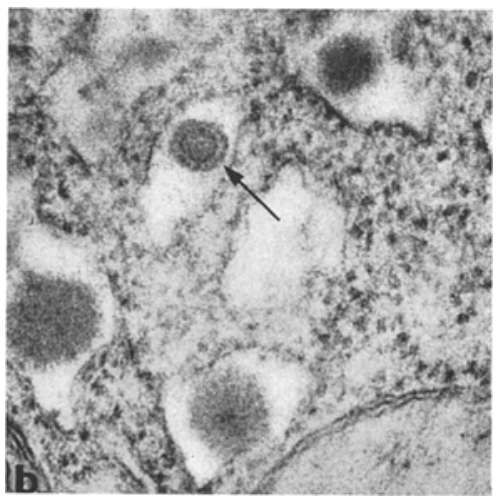

Fig. $28 \mathrm{a}$ and $\mathrm{b}$. Portions of two intra-islet acinar cells which reveal the structure of the virus-like particles situated within cysternae of the rough endoplasmic reticulum. The inner core, membrane bound is $600-650 \AA$. The outer surface is less distinct; the overall diameter is 1000-1100 \&. Approximately $32800 \times(\mathrm{a}), 52800 \times$ (b)

in the intraislet events which accompanied the progression of the diabetic syndrome. The most striking alteration was a result of the rearrangement of islet cells which occurred following or coincidental with the loss of beta cells. Therefore, alpha and beta cells were 

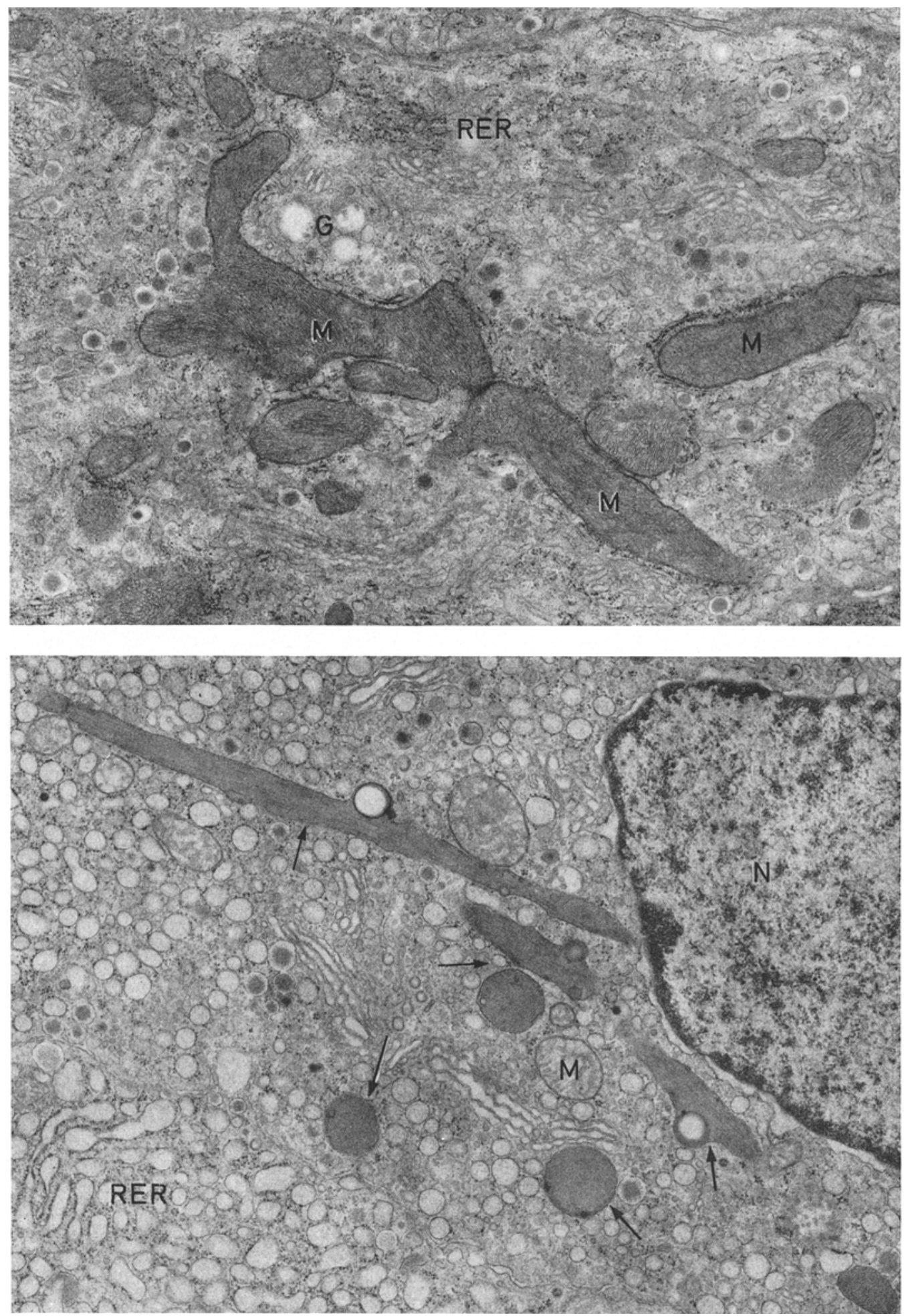

Figs. 29 and 30. Portions of two intact beta cells from diabetic mutant mice in terminal stage of syndrome. Note the large bizarre mitochondria (Fig. 30) and the unidentified elongated structure (Fig. 29). The latter, composed of tightly packed microtubules of fibrils may be several micra in length. Longitudinal and cross sectional viows are present 
intermixed at random throughout the interior of islets, which were as yet undisturbed by the subsequent proliferation of ducts. Although sampling problems were pronounced and the number of labeled islet cells small, there was no evidence that significant numbers of alpha cells underwent mitotic division under the existing conditions. The phenomenon of alpha cell granulolysis recently reported in the presence of hyperglycemia [15], was not an event of importance in this species. Although occasional alpha cells with one or several lysosomes were observed, these organelles were not present in all or most of the cells of diabetic animals. Lyso- islet cells or evidence of islet to duct transformation, rendered unlikely the possibility that the intraislet ducts arose in situ as a result of cell differentiation or transformation. The frequent continuity of proliferating intra- and peri-islet ducts with existing exocrine ducts, the presence of labeled nuclei within small exocrine ducts (Fig. 12 in [9]) during the early period of hyperglycemia, and the ultrastructural similarities of the undifferentiated cells lining both types of duct, all implicated the exocrine ducts as the progenitors of the proliferating intraislet ducts in the mutants.

There was no evidence to support the suggestion

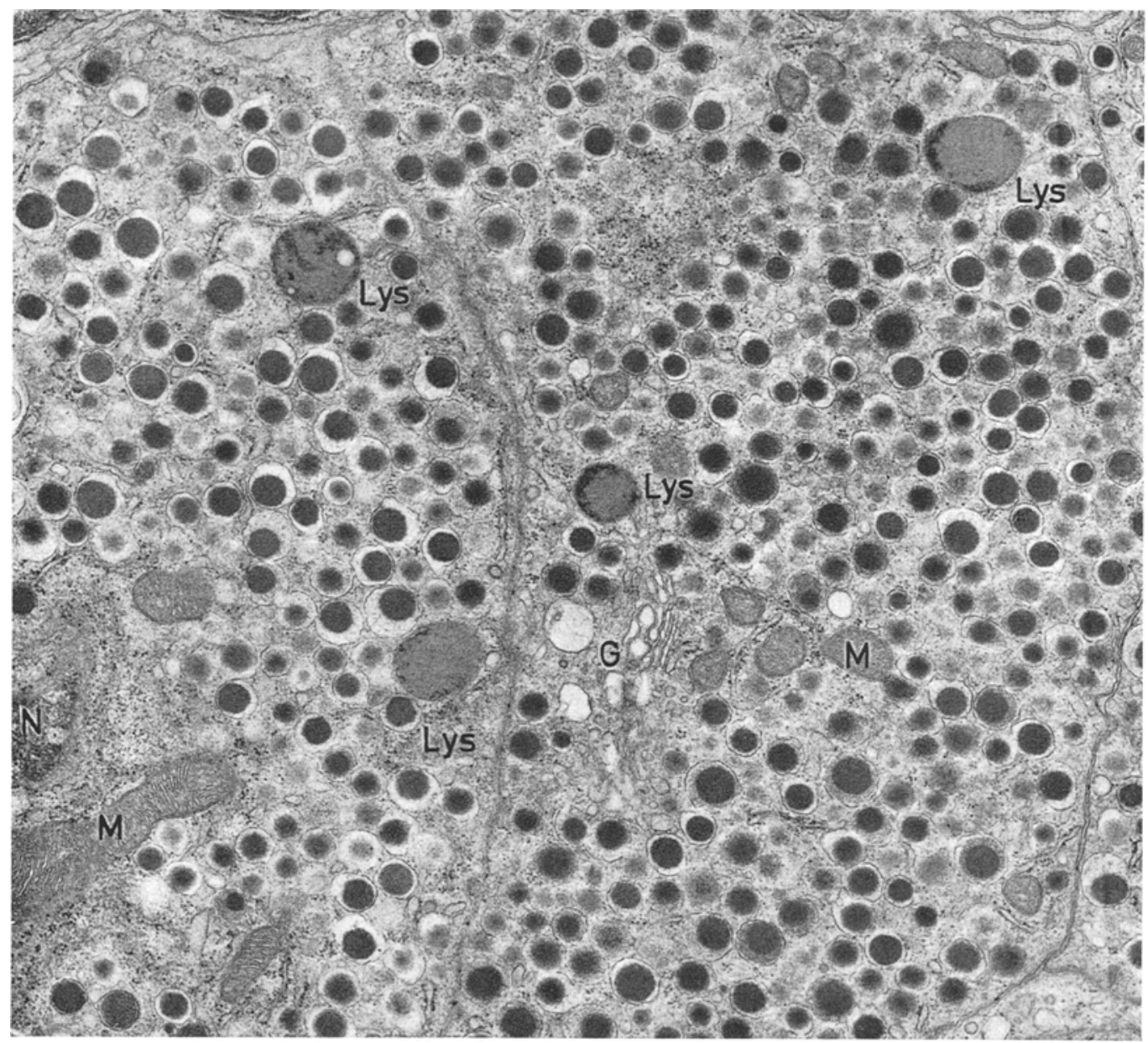

Fig. 31. Alpha cells, diabetic mutant mouse. The normal architecture is evident. The several lysosomes present suggest the phenomenon of granulolysis, but were not frequently identified in other alpha cells. Approximately $14250 \times$

somes were sometimes present in alpha cells of normal mice and no attempt was made to quantitatively doeument a subtle increase in the presence of this organelle in the diabetic mice.

Proliferating ducts. Another unique morphologic feature of this mutation was the phenomenon of ductal proliferation. The absence of either undifferentiated
[2], based on light microscopic examination, that islet cell neogenesis from ducts occurred with frequency, or at all, in the mutants. Evidence to the contrary include the following: 1 . no instances of cells in transition (from duct to islet cell) were observed. 2. Islet cells were not identified on the luminal surface of any duct. In many instances when light microscopic 
examination of epon sections appeared to demonstrate islet cells on the luminal surface of ducts, electron microscopic examination of these areas revealed that the islet cells were in fact separated from the duct lumen by cytoplasmic processes of ductal cells too narrow to be resolved by light microscopy. 3. The positive aldehyde fuchsin staining revealed by some of the ductal cells may reflect the known affinity of basic fuchsin for the protein core of the Paneth or mucin secretory granule. 4 . The presence of proliferating ductal cells was not followed by any evidence of an increase in insulin secretion [1], which would be anticipated if any significant number of new beta cells had been produced.

It should be indicated that the ability of the proliferating ducts to give rise to ciliated cells, mucous or Paneth secretory cells and, presumably pancreatic exocrine cells, supports the initial suggestion [2] that they possessed the developmental potential of embryonic pancreatic ducts. The absence of islet cell neogenesis does not contradict this suggestion for it has not been conclusively proven, in spite of popular belief to the contrary, that the endocrine islet cells are derived embryologically from the pancreatic ductal cells and not from the primitive mesenchyme into which the ducts proliferate [20].

Intraislet acinar cells. The presence of substantial numbers of pancreatic acinar cells within the interior and at the periphery of many islets was yet another unique feature of this mutation. The origin of the "invading" acinar cells was probably dual. Those present at the periphery of an islet may represent the result of a simple rearrangement process. This may have been initiated with the disintegration of a necrotic beta cell, followed by the inward displacement of a peripheral alpha cell, whereupon its position at the islet-acinar interface was taken by a nearby exocrine cell. Those acinar cells present on the luminal surface of the ducts may have been derived by a process of differentiation from the lining epithelial cells, although transition forms were not identified. The presence of an occasional labeled nucleus among these intraislet acinar cells, following the administration of tritiated thymidine, indicated that they shared the ability of acinar cells elsewhere to undergo mitotic division.

Although acinar, alpha and beta cells were frequently in very close proximity to one another, there was no evidence of mixed acinar-islet cells $[16,6]$.

Acknowledgements: The authors wish to acknowledge the skillful technical assistance of Miss Barbara Beach and Miss Pauline Gaudreau, and the help of Dr. S. Ito and Miss J. Mueller, Department of Anatomy, Harvard Medical School, while performing the Radioautography.

\section{References}

1. Chick, W.L., Like, A.A.: Studies in the diabetic mutant mouse: III. Physiological factors associated with alterations in beta cell proliferation. Diabetologia 6, 243-251 (1970).

2. Coleman, D.L., Hummel, K.P.: Studies with the mutation, diabetes, in the mouse. Diabetologia $\mathbf{3}$, $238-248$ (1967).

3. Craighead, J.E.: Pathogenicity of the M \& E variants of the encephalomyocarditis (EMC) virus. II. Lesions of the pancreas, parotid and lacrimal glands. Amer. J. Path. 48, 375-386 (1966).

4. - MeLane, M.F.: Diabetes mellitus: induction in mice by encephalomyocarditis (EMC) virus. Science 162, 913-914 (1968).

5. Karnovsky, M.J.: A formaldehyde-glutaraldehyde fixative of high osmolality for use in electron microscopy. J. cell. Biol. 27, 137A (1965).

6. Leduc, E.H., Jones, E.E.: Acinar-islet cell transformation in mouse pancreas. J. Ultrastructure Res. 24, $165-169$ (1968).

7. Like, A.A.: The uptake of exogenous peroxidase by the beta cells of the islets of Langerhans. Amer. J. Path, in Press 1970.

8. - Chick, W.L.: Mitotic division in pancreatic beta cells. Science 163, $941-943$ (1969).

9. - - Studies in the diabetic mutant mouse: I. Light microscopy and radioautography of pancreatic islets. Diabetologia 6, 207-215 (1970).

10. - Miki, E.: Diabetic syndrome in sand rats IV. Morphologic changes in islet tissue. Diabetologia $3,143-$ 166 (1967).

11. - Jones, E.E.: Studies on experimental diabetes in the Wellesley hybrid mouse. IV. Morphologic changes in islet tissue. Diabetologia 3, 179-187 (1967).

12. - Steinke, J., Jones, E.E., Cahill, G.F., Jr.: Pancreatic studies in mice with spontaneous diabetes mellitus. Amer. J. Path. 46, 621-644 (1965).

13. Luft, J.H.: Improvements in epoxy resin embedding methods. J. biophys. biochem. Cytol. 9, 409-414 (1961).

14. Luse, S.A., Caramia, F., Gerritsen, G., Dulin, W.E.: Spontaneous diabetes mellitus in the Chinese hamster : An electron microscopic study of the islets of Langerhans. Diabetologia 3, 97-108 (1967).

15. Orci, L., Junod, A., Pictet, R., Renold, A.E., Rouiller, C.: Granulolysis in A cells of endocrine pancreas in spontaneous and experimental diabetes in animals. J. cell. Biol. 38, 462-466 (1968).

16. Pictet, R., Orci, L., Gonet, A.E., Rouiller, C., Renold, A.E.: Ultrastructural studies of the hyperplastic islets of Langerhans of spiny mice (Acomys Cahirinus) before and during the development of hyperglycemia. Diabetologia 3, 188-211 (1967).

17. Trier, J.S.: Morphology of the epithelium of the small intestine: Handbook of Physiology, Section 6: Alimentary canal III: Intestinal absorption, pp. 1125 1175. Washington, D. C.: American Physiological Soeiety 1965.

18. Venable, J., Coggeshall, R.: A simplified lead citrate stain for use in electron microscopy. J. cell. Biol. 25, $407-408$ (1965).

19. Volk, B.W., Lazarus, S.S.: Ultramicroseopic evolution of B-cell destruction in diabetic dogs. Proc. Internat. Wenner-Gren Symposium, pp. 143-155. Uppsala and Stockholm: Pergamon Press 1964.

20. Wessels, N.K.: In: Epithelial-Mesenchymal Interactions, Fleishmajer, R., Billingham, R.E., Eds. Baltimore: Williams \& Wilkins Co. 1968.
Arthur A. Like, M. D.

Elliott P. Joslin. Research Laboratory 170 Pilgrim Road

Boston, Massachusetts 02215, USA 